Report of Investigations 2006-1

\title{
YUKON FLATS BASIN, ALASKA: RESERVOIR CHARACTERIZATION STUDY
}

\author{
by \\ R.R. Reifenstuhl
}

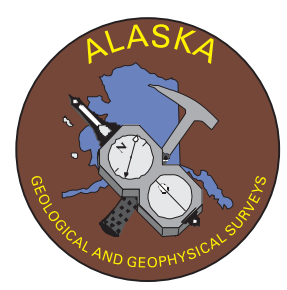

Published by

STATE OF ALASKA

DEPARTMENT OF NATURAL RESOURCES

DIVISION OF GEOLOGICAL \& GEOPHYSICAL SURVEYS 
Report of Investigations 2006-1

\section{YUKON FLATS BASIN, ALASKA: RESERVOIR CHARACTERIZATION STUDY}

by

R.R. Reifenstuhl

2006

This DGGS Report of Investigations is a final report of scientific research. It has received technical review and may be cited as an agency publication. 


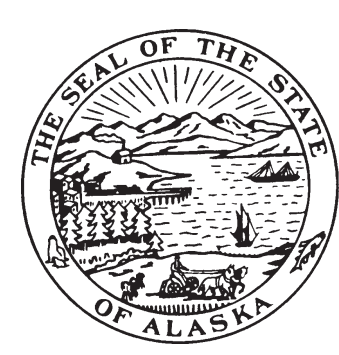

STATE OF ALASKA

Frank Murkowski, Governor

DEPARTMENT OF NATURAL RESOURCES

Mike Menge, Commissioner

\title{
DIVISION OF GEOLOGICAL \& GEOPHYSICAL SURVEYS Robert F. Swenson, Acting State Geologist and Acting Director
}

Division of Geological \& Geophysical Surveys publications can be inspected at the following locations. Address mail orders to the Fairbanks office.

\author{
Alaska Division of Geological \\ \& Geophysical Surveys \\ 3354 College Road \\ University of Alaska Anchorage Library \\ Fairbanks, Alaska 99709-3707 \\ 3211 Providence Drive \\ Anchorage, Alaska 99508 \\ Elmer E. Rasmuson Library \\ University of Alaska Fairbanks \\ Alaska Resource Library \\ and Information Services (ARLIS) \\ Fairbanks, Alaska 99775-1005 \\ 3150 C Street, Suite 100 \\ Anchorage, Alaska 99503
}

\author{
Alaska State Library \\ State Office Building, 8th Floor \\ 333 Willoughby Avenue \\ Juneau, Alaska 99811-0571
}

This publication released by the Division of Geological \& Geophysical Surveys was produced and printed in Fairbanks, Alaska at a cost of $\$ 3$ per copy. Publication is required by Alaska Statute 41, "to determine the potential of Alaskan land for production of metals, minerals, fuels, and geothermal resources; the location and supplies of groundwater and construction materials; the potential geologic hazards to buildings, roads, bridges, and other installations and structures; and shall conduct such other surveys and investigations as will advance knowledge of the geology of Alaska.” 


\section{CONTENTS}

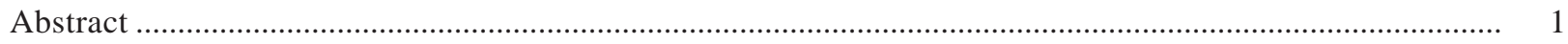

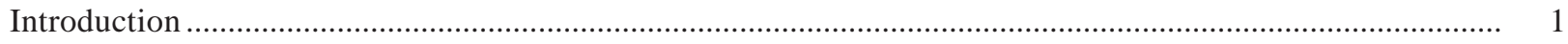

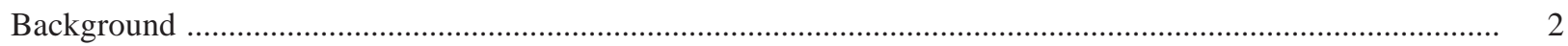

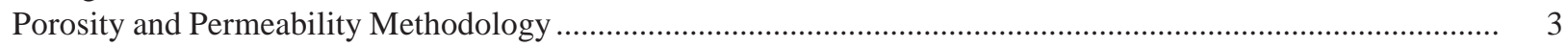

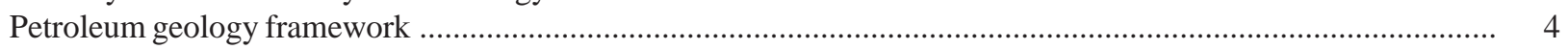

Porosity, permeability, and petrographic overview of drill core and outcrop samples .........................................

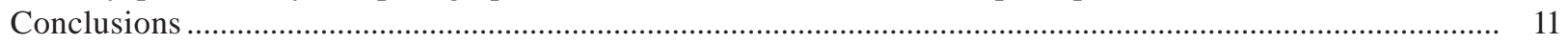

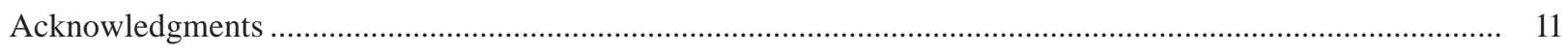

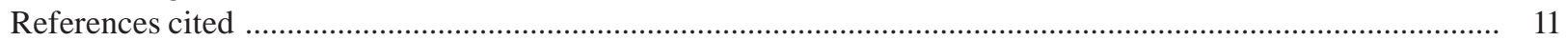

\section{TABLES}

Table 1. Porosity, permeability, location, age (if known), lithology, and vitrinite reflectance (Ro) for 26 Exxon drill core samples from the Yukon Flats basin and basin perimeter ................................ 5

2. Summary of petrographic analyses of framework grain size mean, maximum, and minimum for the Exxon drill core samples from Yukon Flats basin and basin perimeter ................. 7

3. Porosity, permeability, location, and stratigraphic information for 11 outcrop samples from the Yukon Flats basin

\section{FIGURES}

Figure 1. Location map with color Digital Elevation Model (DEM) base showing east-central Alaska and Yukon Flats basin

2. General geologic map of the Yukon Flats basin and basin margin .

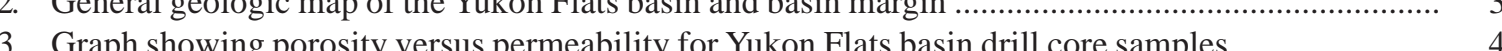

4. Graph showing porosity versus permeability for Yukon Flats basin-fill sandstone; typically Tertiary age

5. Quartz-Feldspar-Lithic Folk sandstone classification diagram, Yukon Flats basin core hole samples

6. Tectonic setting plot [quartz-feldspar-lithic (includes chert)] of Yukon Flats basin core hole samples

7. Tectonic setting plot [quartz (total)-feldspar-lithic] of Yukon Flats basin core hole samples

\section{APPENDICES}

Appx 1. Summary of petrography 13

2. Yukon Flat basin and basin perimeter drill core photomicrographs 20 


\title{
YUKON FLATS BASIN, ALASKA: RESERVOIR CHARACTERIZATION STUDY
}

\author{
by \\ Rocky R. Reifenstuhl ${ }^{1}$
}

\begin{abstract}
The Yukon Flats basin is located in east-central Interior Alaska. To characterize the potential siliciclastic reservoirs of selected Tertiary outcrop samples and selected Exxon core material, 26 Exxon drill core samples were analyzed for porosity and permeability (P\&P), and petrographic composition. The Exxon drill hole locations were on the basin margins. In addition to the core samples, 40 outcrop samples were collected from Tertiary basin fill. Gravity and seismic geophysical information suggest 4,575-m-thick depocenters locally. Potential energy resources include coalbed methane, shalebed methane, and conventional gas and oil. A summary of the P\&P data from the basin margin cores includes porosities of 1.1 to 11.7 percent (average about 4 percent) and permeabilities of 0.001 to 171.3 millidarcies (average $0.4 \mathrm{md}$ ). A summary of the P\&P data from the 11 Yukon Flats basin outcrop samples includes porosities of 2.7 to 38.7 percent (average about 13 percent) and permeabilities of 0.006 to $203 \mathrm{md}$ (average about $20 \mathrm{md}$ ). $\mathrm{P} \& \mathrm{P}$ reduction is common in the vast majority of the drill core sandstones, in which ductile grains (shale, mudstone, argillite, and phyllite) total from 2 to 27 percent. Potential reservoir sandstones crop out northeast of Rampart, along the Yukon River, where a more-than-1-km-thick stratigraphy of probable Eocene units includes thick, meandering stream deposits of sandstone, conglomerate, and lignite coal beds up to $10 \mathrm{~cm}$ thick. At Schieffelin Creek, on the Yukon River, several hundred meters of Eocene to Oligocene fluvial sandstone, pebbly sandstone with lesser conglomerate, and minor coal are well exposed and yield good petrophysical characteristics ( 8.8 md permeability and 15.8 percent porosity). Petrographically, drill core samples from the Yukon Flats basin perimeter wells range from litharenite sandstone (10 samples), to sublitharenite sandstone ( 1 sample), to quartzarenite sandstone ( 1 sample), and are erosional products of a provenance dominated by quartz-rich and chert-rich rocks, with lesser contributions from quartz-poor rocks such as shale, mafic and intermediate igneous rocks, and metamorphic rocks. Seven of the 12 pointcounted drill core sandstones are volcaniclastic-rich and Paleogene to Eocene age.
\end{abstract}

\section{INTRODUCTION}

The Yukon Flats basin is located in east-central Interior Alaska (fig. 1). The goal of this study is to characterize the potential siliciclastic reservoirs of selected Tertiary outcrop samples and selected basin-perimeter, drill hole core material. This reservoir characterization study is an element of the federallyfunded Yukon Flats basin project, a collaborative effort by the U.S. Geological Survey (USGS) and DGGS to evaluate the basin's petroleum potential. Integration of this study with the USGS work will result in a more accurate evaluation of the principal target reservoirs and energy potential of the Yukon Flats basin. More information regarding the USGS oil and gas assessment of the Yukon Flats can be found at: http://pubs.usgs.gov/fs/ 2004/3121/ and http://energy.cr.usgs.gov/oilgas/noga/

Twenty-six Exxon drill core samples were analyzed for porosity and permeability; 12 of these were analyzed petrographically and point counted during 2002. The Exxon drill hole locations were sited on the basin margins. In addition to the core samples, about 40 outcrop samples were collected during July and September 2002 fieldwork. Ten of the outcrop samples were analyzed for porosity and permeability, and 15 were examined petrographically.

To summarize and place into perspective, Yukon Flats basin porosity and permeability data are described using the classification framework of North (1985): Porosity (in percent), $0-5$ negligible, $5-10$ poor, $10-15$ fair, 15-20 good, $>20$ very good; Permeability (in millidarcies), $<1.0-15$ poor to fair, $15-50$ moderate, 50 250 good, 250-1,000 very good, $>1,000$ excellent. Porosity values of Yukon Flats basin core samples (with number of samples falling into each range shown in parentheses) are: negligible (15), poor (6) and fair (2), and permeability is poor to fair (23). Porosity values of Yukon Flats basin outcrop samples are: negligible (2), poor (3) fair (1) and good (3), and permeability is poor to fair (7), and moderate (3).

The core material is from shallow core holes drilled by Exxon from 1985 through 1987 primarily to determine source rock potential around the Yukon Flats basin margin (fig. 2). Although the main objective of the Exxon drilling was to evaluate source rock potential near the Yukon Flats basin margin, reservoir potential was a sub-

\footnotetext{
${ }^{1}$ Alaska Division of Geological \& Geophysical Surveys, 3354 College Rd., Fairbanks, Alaska 99709-3707
}

Email: rocky@dnr.state.ak.us 


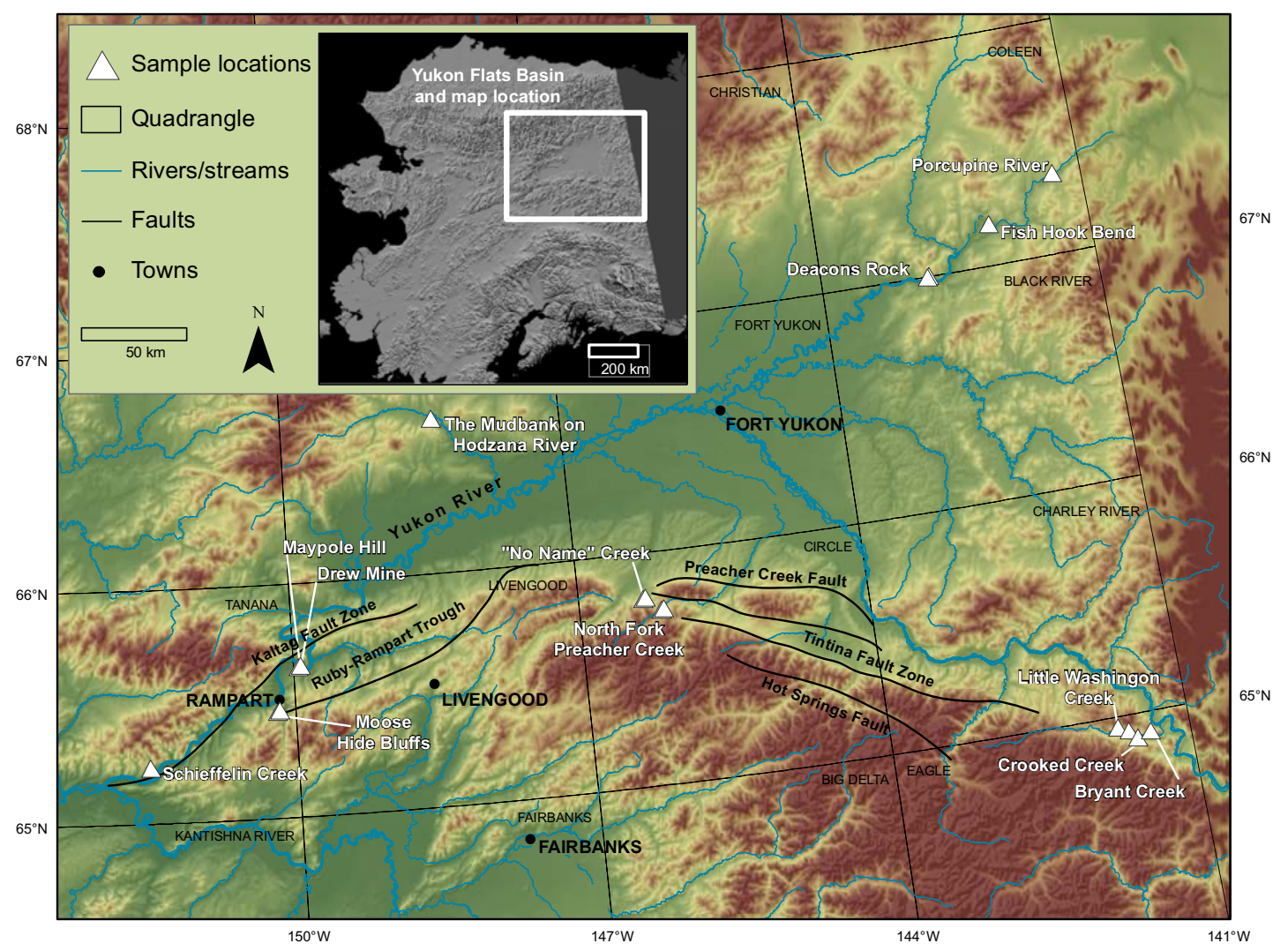

Figure 1. Location map with color Digital Elevation Model (DEM) base showing east-central Alaska and Yukon Flats basin. Figure shows major geologic units, field sample locations, quadrangle index, major fault zones, and reported localities of tasmanite (organic shale containing a significant percentage of palynomorphs of the genus Tasmanites).

ordinate consideration. As a consequence, most non Tertiary-age sandstones yield poor reservoir characteristics. Doyon Native Corporation currently holds the core material and provided access. Thousands of meters of core material were examined; 26 potential reservoir sandstones were selected. These 26 siliciclastic sandstone specimens were selected based on visual attributes suggesting potential reservoir characteristics.

\section{BACKGROUND}

Reservoirs are key components of petroleum systems - they provide the storage for hydrocarbons into which companies drill to extract oil and gas. Petroleum reservoir characterization is the complex process of identifying and quantifying properties that influence the distribution and migration of oil or gas within a reservoir. Studying the geologic details of known and potential reservoirs allows for simulation of different economic scenarios essential to reservoir development and production management. Reservoir characterization studies can be done from well core, down-hole geophysical information, surface geophysical information, or surface bedrock exposures. The ultimate goal of this reconnaissance-level study is to develop reasonable physical descriptions of potential reservoirs that will minimize exploration, development, and production costs as well as financial risks while maximizing hydrocarbon recovery potential.

In this report, potential reservoirs are being characterized and quantified using petrophysics (porosity and permeability) and detailed thinsection petrography. Petrographic study includes counting sandstone grain types, measuring grain size, determining what kind of cement binds the sandstone, and when, during the geologic history of the sandstone, that cement formed. Additionally, the details and distribution of the sandstone reservoir rock types are considered within a reconnaissance geologic framework. Reconnaissance geologic mapping indicates that sandstone bedrock exposures are relatively uncommon within the basin. 


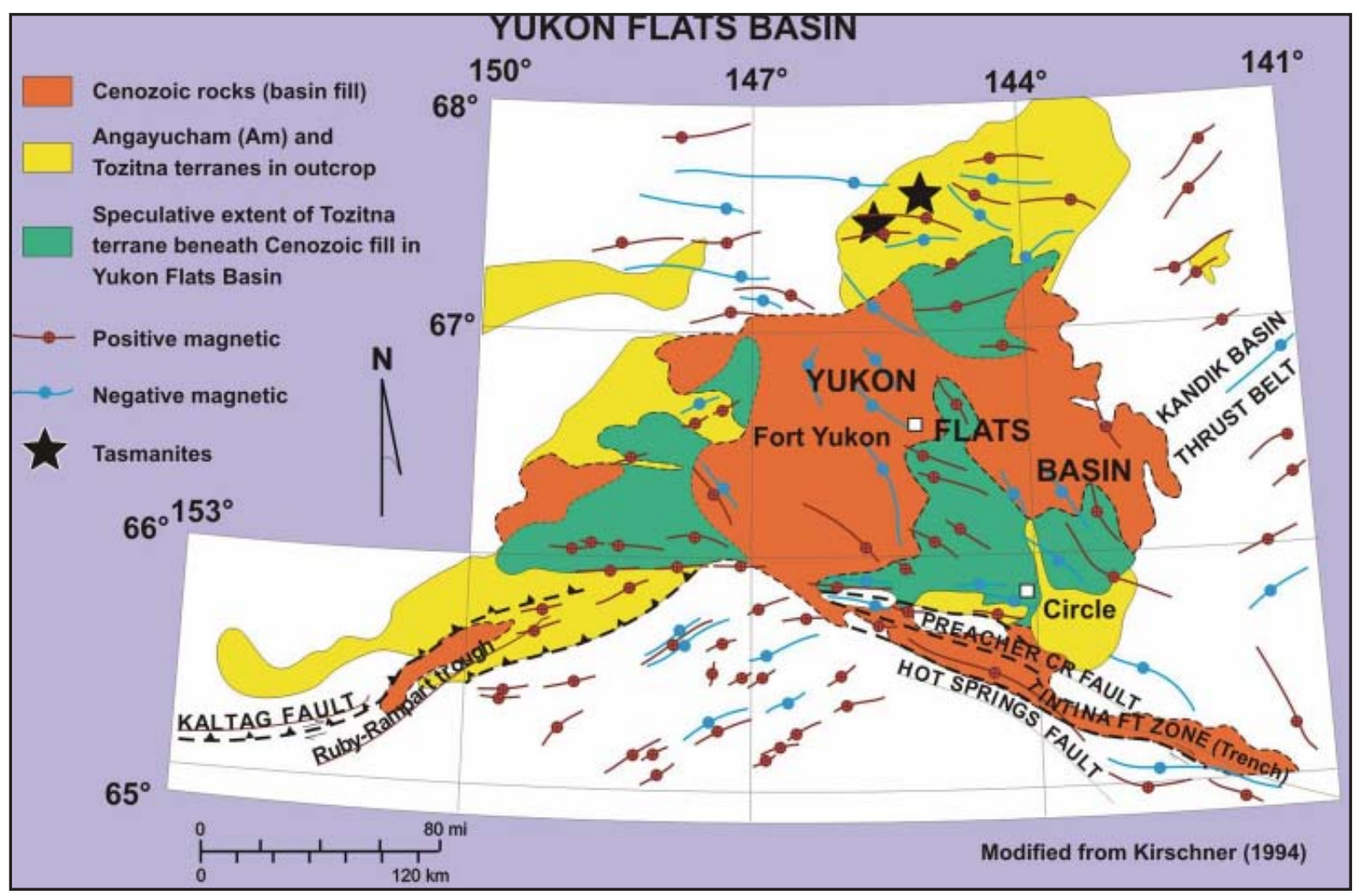

Figure 2. General geologic map of the Yukon Flats basin and basin margin. General airborne magnetic trends are shown, along with localities of reported tasmanite (an organic-rich shale with abundant palynomorphs of the genus Tasmanites). From Scott and others (1998) based on Kirschner (1994).

\section{POROSITY AND PERMEABILITY METHODOLOGY}

Porosity and permeability (P\&P) data obtained from core and surface outcrops can serve as a useful screening tool in the search for potential petroleum reservoirs. P\&P data are useful in evaluating reservoir potential when they are integrated with petrographic details, rock body geometry, and depositional environment. Porosity is the percent volume of pore space of the rock that is available to store oil or gas. Permeability (reported as millidarcies, or $\mathrm{md}$ ) is a measure of how well connected these pore spaces are. If permeability is reasonably high, hydrocarbons in the pore space of a reservoir can flow through the rock and reach the wellhead for successful economic oil and gas recovery. However, it is possible to have oil trapped in a reservoir with little or no permeability, making hydrocarbon mobility and extraction difficult. Low porosity and permeability of reservoirs are significant technical problems that limit production in petroleum basins worldwide. P\&P data have been obtained from producing reservoirs and potential reservoirs for decades by petroleum companies operating throughout Alaska, but very little of this information is publicly available. Likewise, although state, federal, and university geologists may have collected potential reservoir data from the Yukon Flats basin, no public or published source exists for this information.

From the Yukon Flats basin and basin perimeter, 26 drill hole core sandstones and 10 outcrop sandstones were selected for P\&P analyses. Fifteen outcrop-derived sandstone thinsections were petrographically examined. Twelve of the drill core samples were selected for additional detailed petrographic point counting analysis. For the porosity and permeability analyses, each sample is drilled, resulting in a 2.5 -cm-diameter core plug. Next the plug is tested with nitrogen gas for its flow capacity. The sandstones are measured for grain volume, bulk volume, and sample weight. These quantitative data are necessary to calculate porosity, permeability, and grain density. Details of individual sandstone grain boundaries, sandstone cement type, geologic timing of cementation, and visible porosity are evaluated using thinsections and a petrographic microscope.

Petrographic point counting involves selecting representative fine-grained sandstones from rock units of interest and systematically identifying and tabulating the mineral composition of 400 framework grains. Results are plotted on diagrams that yield a sandstone classification and an inferred tectonic environment of deposition for the sandstone. These are useful for comparison 
of sandstones within the Yukon Flats basin and for comparison of sandstone reservoirs globally. The composition of potential reservoir sandstones is fundamental to understanding its viability as a reservoir rock.

\section{PETROLEUM GEOLOGY FRAMEWORK}

The Yukon Flats basin is located in east-central Alaska, between the Trans-Alaska pipeline and the Canadian border, and contains known coal-bearing strata on the western, southwestern, and southeastern margins. The Yukon Flats basin is considered to be a latest Cretaceous and Cenozoic sedimentary basin that formed due to extensional forces. These pull-apart forces are associated with movement along the well known and well documented Tintina and Kaltag fault systems (Kirschner, 1994; fig. 1). The Tintina fault system extends southeastward into Yukon Territory, Canada, where it forms the southwest boundary of the Whitehorse trough. The Tintina and Kaltag faults are similar in nature to the well known San Andreas fault system in southern California.

Gravity and seismic geophysical information suggest that this Yukon Flats basin is locally filled with at least $5,000 \mathrm{~m}$ of nonmarine sediments consisting of three thick rock packages, each including different proportions of lake and river sediments (Kirschner, 1994). The lake sediments in the Yukon Flats basin may include oil-prone or gas-prone organic material. Oil and gas plays include reservoir sandstones that might trap hydrocarbons in either a fault-related structure or in a structure that is formed by a non-permeable layer (topseal) overlying a porous and permeable sandstone layer (reservoir). Lake sediments can act as both topseals and as source rock. Petroleum generation is estimated to be possible below the 2,130 to 3,050 m region based on a typical increase of temperature with depth gradient that is reasonable for an interior basin (Kirschner, 1994; R.G. Stanley, USGS, personal commun., 2002). Potential energy resources include coalbed gas, shalebed methane, conventional gas, and oil.

\section{POROSITY, PERMEABILITY, AND PETROGRAPHIC OVERVIEW OF DRILL CORE AND OUTCROP SAMPLES}

A summary of the porosity and permeability data from the 24 Yukon Flats basin margin drill cores includes porosity of 1.1 to 11.7 percent (average about 4 percent) and permeability of 0.001 to $171.3 \mathrm{md}$ (average about $0.4 \mathrm{md}$; fig. 3 ; table 1 ). A summary of the porosity and

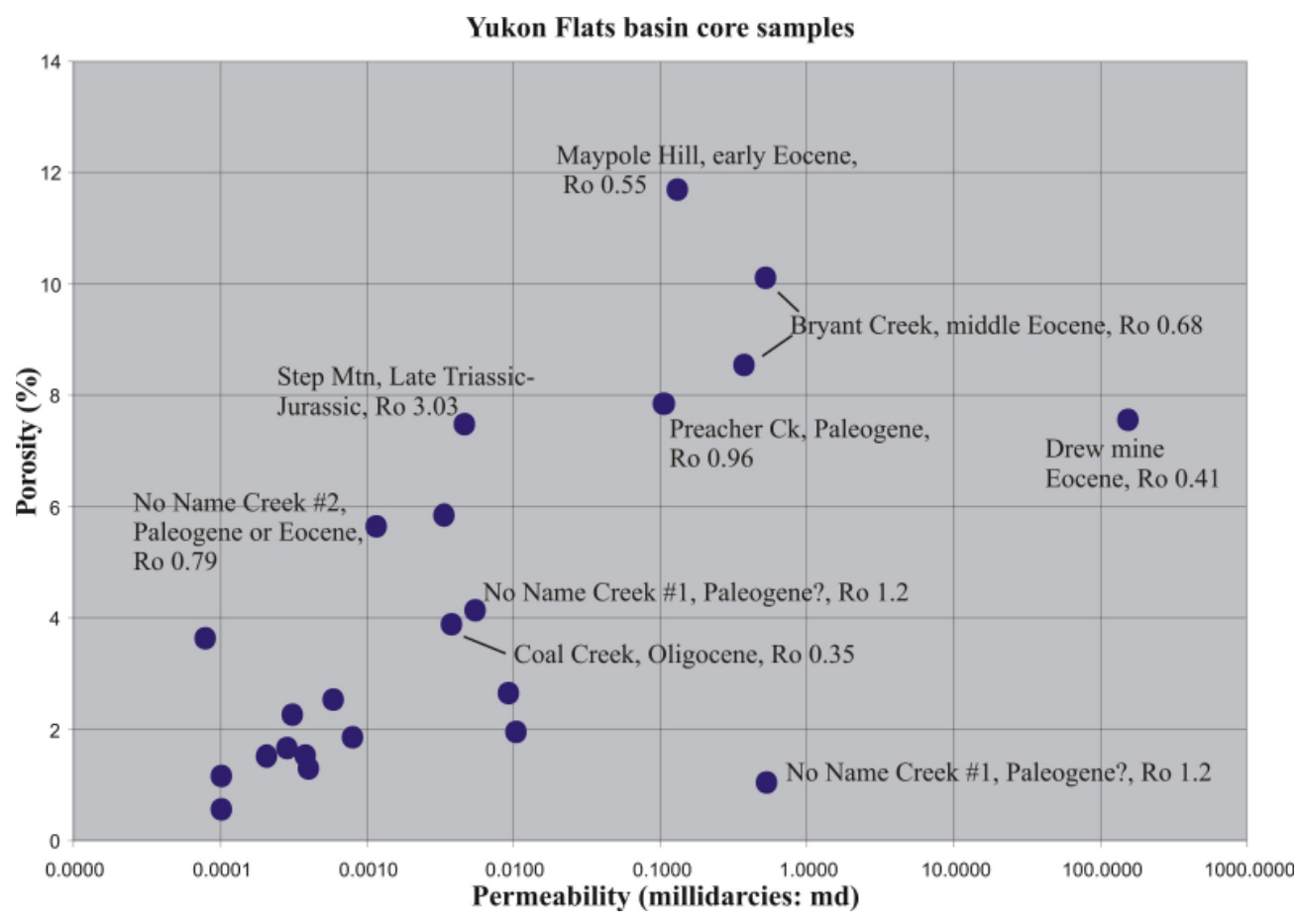

Figure 3. Porosity versus permeability for Yukon Flats basin drill core samples. These samples are from the Exxon shallow drill core material from their sites around the perimeter of the Yukon Flats basin. Core plugs (2.5-cm diameter) are cut from the Exxon core. The plug is then measured for its capacity for flow to nitrogen gas as well as grain volume, bulk volume, and weight. Porosity, permeability, and grain density are derived from these data and are critical information related to oil and gas reservoirs. 
Table 1. Porosity, permeability, location, age (if known), lithology, and vitrinite reflectance (Ro) for 26 Exxon drill core samples from the Yukon Flats basin and basin perimeter. Analyses by Core Laboratories, Denver, Colorado. See text for explanation of porosity and permeability methodology. See table 2 for framework grain summary statistics; see appendix for photomicrographs.

\begin{tabular}{|c|c|c|c|c|c|}
\hline \multirow{2}{*}{$\begin{array}{c}\text { Sample } \\
\text { Identification } \\
\text { Number } \\
\end{array}$} & \multicolumn{2}{|c|}{ Permeability } & \multirow{2}{*}{$\begin{array}{c}\text { Helium } \\
\text { Porosity } \\
(\%) \\
\end{array}$} & \multirow{2}{*}{$\begin{array}{c}\text { Grain } \\
\text { Density } \\
\text { (g/cc) } \\
\end{array}$} & \multirow[b]{2}{*}{ Rock Unit } \\
\hline & $\begin{array}{l}\text { Air } \\
\text { (md) }\end{array}$ & $\begin{array}{c}\text { Klink } \\
\text { (md) }\end{array}$ & & & \\
\hline $85-23-23$ & 0.6975 & 0.5171 & 10.12 & 2.65 & $\begin{array}{l}\text { Bryant Creek, early to middle Eocene, conglomerate, } \\
\text { Ro }=0.60-0.76\end{array}$ \\
\hline $85-23-66$ & 0.5128 & 0.3666 & 8.56 & 2.59 & $\begin{array}{l}\text { Bryant Creek, early to middle Eocene, sandstone?, } \\
\text { Ro }=0.60-0.76\end{array}$ \\
\hline $85-23-136$ & 0.0006 & 0.0001 & 3.65 & 2.72 & $\begin{array}{l}\text { Bryant Creek, early to middle Eocene, sandstone, } \\
\mathrm{Ro}=0.60-0.76\end{array}$ \\
\hline $85-26-68.5$ & 0.0016 & 0.0003 & 2.27 & 2.68 & $\begin{array}{l}\text { Eagle trough, middle to late Albian, sandstone, } \\
\text { Ro }=0.53-0.61\end{array}$ \\
\hline $85-26-106.5$ & 0.0033 & 0.0008 & 1.87 & 2.67 & $\begin{array}{l}\text { Eagle trough, middle to late Albian sandstone, } \\
\mathrm{Ro}=0.53-0.61\end{array}$ \\
\hline $85-26-110.5$ & 0.0243 & 0.0103 & 1.96 & 2.67 & $\begin{array}{l}\text { Eagle trough, middle to late Albian sandstone, } \\
\mathrm{Ro}=0.53-0.61\end{array}$ \\
\hline $85-27-22$ & 0.0127 & 0.0046 & 7.50 & 2.65 & $\begin{array}{l}\text { Step Mountain, Late Triassic to Jurassic shale, } \\
\mathrm{Ro}_{0}=3.03\end{array}$ \\
\hline $85-30-121$ & 172.31766 & 153.56833 & 7.57 & 2.76 & Drew Mine, early Eocene sandstone, $\mathrm{Ro}=0.37-0.45$ \\
\hline $85-31-18$ & 0.2045 & 0.1287 & 11.71 & 2.69 & Maypole Hill, early Eocene sandstone, $\mathrm{Ro}=0.52-0.59$ \\
\hline $86-3-8$ & 0.0108 & 0.0037 & 3.90 & 3.04 & $\begin{array}{l}\text { Coal Creek, Oligocene, lithology not on core record, } \\
\text { Ro }=0.35\end{array}$ \\
\hline $86-5-38$ & 0.1712 & 0.1051 & 7.86 & 2.59 & $\begin{array}{l}\text { Preacher Creek, Paleogene, conglomerate, } \mathrm{Ro}=0.90 \text { - } \\
1.02\end{array}$ \\
\hline $86-5-67$ & 0.0026 & 0.0006 & 2.54 & 2.72 & Preacher Creek, Paleogene, claystone, $\mathrm{Ro}=0.90-1.02$ \\
\hline $86-6-17$ & 0.0015 & 0.0003 & 1.68 & 2.64 & $\begin{array}{l}\text { No Name Creek No. 1, Paleocene or Eocene, } \\
\text { lithology?, Ro=.96-1.0 }\end{array}$ \\
\hline $86-6-41$ & 0.0012 & 0.0002 & 1.54 & 2.67 & $\begin{array}{l}\text { No Name Creek No. } 1 \text {, Paleocene or Eocene, silty } \\
\text { shale, } R==.96-1.0\end{array}$ \\
\hline $86-7-37$ & 0.0019 & 0.0004 & 1.55 & 2.67 & $\begin{array}{l}\text { No Name Creek No. 2, Paleocene or Eocene } \\
\text { sandstone }\end{array}$ \\
\hline $86-7-66$ & 0.0020 & 0.0004 & 1.31 & 2.66 & $\begin{array}{l}\text { No Name Creek No. 2, Paleocene or Eocene } \\
\text { sandstone }\end{array}$ \\
\hline $86-7-96$ & 0.0004 & 0.0001 & 1.18 & 2.67 & No Name Creek No. 2, Paleocene or Eocene siltstone \\
\hline $86-7-120$ & 0.0099 & 0.0033 & 5.86 & 2.71 & $\begin{array}{l}\text { No Name Creek No. 2, Paleocene or Eocene } \\
\text { sandstone }\end{array}$ \\
\hline $86-8-54$ & 0.0004 & 0.0001 & 0.58 & 2.73 & $\begin{array}{l}\text { No Name Creek No. 2, late Paleocene-Eocene } \\
\text { siltstone, Ro=-.70-.87 }\end{array}$ \\
\hline $86-9-35$ & 0.7107 & 0.5281 & 1.05 & 2.72 & $\begin{array}{l}\text { No Name Creek No. } 1 \text {, probable Paleogene siltstone, } \\
\text { Ro }=1.19\end{array}$ \\
\hline $86-9-39$ & 0.0145 & 0.0054 & 4.16 & 2.67 & $\begin{array}{l}\text { No Name Creek No. 1, probable Paleogene } \\
\text { sandstone, Ro=1.19 }\end{array}$ \\
\hline $87-8-95$ & 0.0044 & 0.0011 & 5.66 & 2.65 & $\begin{array}{l}\text { Hodzana River No. 2, age?, lithology not recorded, } \\
\text { Ro=3.41=3.97 }\end{array}$ \\
\hline $87-10-92$ & 0.0220 & 0.0091 & 2.66 & 2.67 & $\begin{array}{l}\text { Grayling Fork Jurassic-Cretaceous, lithology?, } \\
\text { Ro=4.26-4.92 }\end{array}$ \\
\hline $86-9-59.5$ & & Sample F & ailed & & $\begin{array}{l}\text { No Name Creek No. } 1 \text {, probable Paleogene } \\
\text { conglomerate, } \mathrm{Ro}=1.19\end{array}$ \\
\hline $85-30-100$ & Sample & nsuitable & & 2.58 & Drew Mine, early Eocene sandstone, $\mathrm{Ro}=0.37-0.45$ \\
\hline $86-8-60$ & Sample & nsuitable & & 2.62 & $\begin{array}{l}\text { No Name Creek No. 2, late Paleocene- Eocene } \\
\text { siltstone, } \mathrm{Ro}=.70-.87\end{array}$ \\
\hline
\end{tabular}


permeability data from the 11 Yukon Flats basin outcrop samples includes porosity of 2.7 to 38.7 percent (average about 13 percent) and permeability of 0.006 to 203 md (average about 20 md; fig. 4; table 3). Summarizing all Yukon Flats basin petrophysical data for outcrop samples using the qualitative terminology of North (1985) (with numbers of samples in parentheses) yields: porosity that is negligible (2), poor (3), fair (1), good (3); permeability results that are poor to fair (7), and moderate (3); and core sample porosity that is negligible (15), poor (6) and fair (2); and permeability that is poor to fair (23).

Distinguishing between analytical data from the Exxon basin-margin drill core samples and the DGGScollected, basin-fill, outcrop samples is important, as outcrop samples consistently yield higher petrophysical values relative to core samples

Exxon's shallow drilling program focused primarily on the source rock potential of the basin-margin rocks. These potential hydrocarbon source rocks would, presumably, extend beneath the Yukon Flats basin, charging hydrocarbon plays within the basin. Reservoir rock was a secondary objective for the Exxon basin and basinmargin shallow drilling project. Porosity and permeability of the sandstone samples from the shallow drilling program are relatively low, as a consequence of Exxon's focus on source rock. In summary, this small sample number (24) of basin and basin-margin sand- stones indicates generally poor petrophysical characteristics for hydrocarbon reservoirs (fig. 3; tables 1 and 2). In contrast, DGGS-collected outcrop samples from the Tertiary-age Yukon Flats basin fill suggest locally good reservoir potential with encouraging porosity and permeability characteristics (fig. 4; table 3).

Petrography of Yukon Flats basin-perimeter drill core samples ranges from litharenite sandstone (10 samples), sublitharenite sandstone (1 sample) to quartzarenite sandstone (1 sample; fig. 5). The petrographic protocol is that of Decker (1985), Van der Plas and Tobi (1965), and Dickinson (1970); 300 framework grains were counted on each of 12 drill core thinsections. Only one drill core sandstone (SA86-27-22) is composed of more than 95 percent quartz; it plots as a compositionally pure quartzarenite. This basin-margin sandstone from the Step Mountain area east of the Yukon Flats basin is Late Triassic to Jurassic age, with less than 0.01 md permeability, and about eight percent porosity. Compositionally, the quartzarenite is anomalous quartz rich relative to the remaining 11 drill core samples.

Porosity and permeability reduction is common in the vast majority of the drill core sandstones. Ductile grains, such as shale, mudstone, argillite, and phyllite, total from 2 to 27 percent, averaging about 13 percent in the drill core sandstone samples. Abundance of ductile rock fragments in most of the drill core sandstones decreases their viability as potential reservoirs due to the

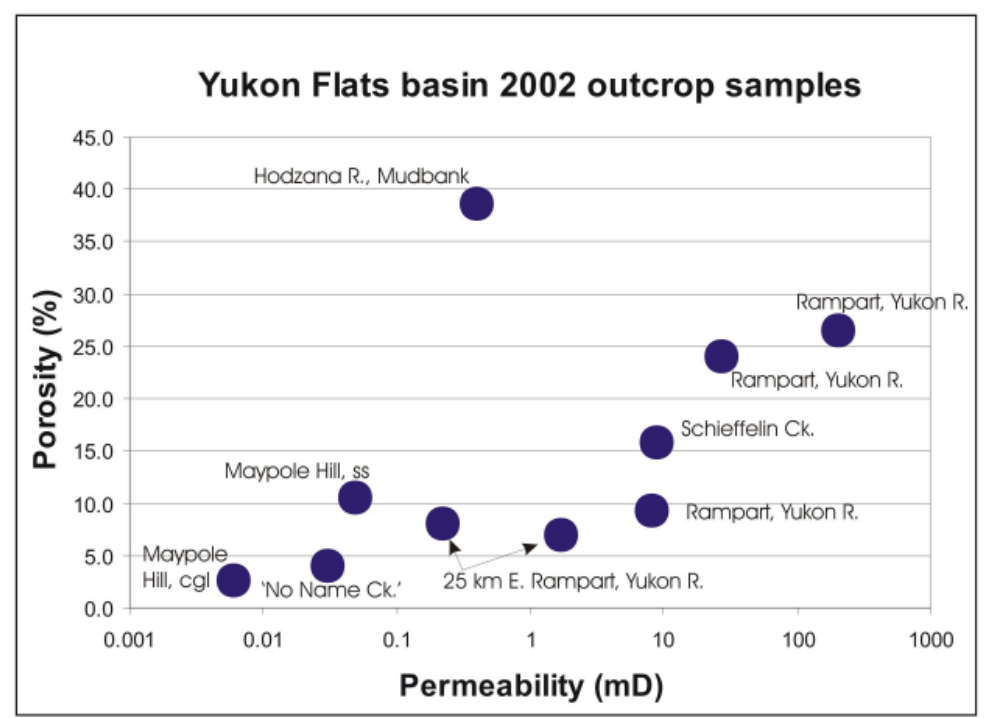

Figure 4. Porosity (percent) on vertical axis versus permeability (millidarcies [md]) on horizontal axis for Yukon Flats basin-fill sandstone; typically Tertiary age. Core plugs (2.5-cm diameter) are cut from the outcrop sample, which is then measured for its capacity for flow to nitrogen gas as well as for grain volume, bulk volume, and weight. Porosity, permeability, and grain density are derived from these data and are critical information related to oil and gas reservoirs. 
Yukon Flats Basin, Alaska: Reservoir characterization study 7
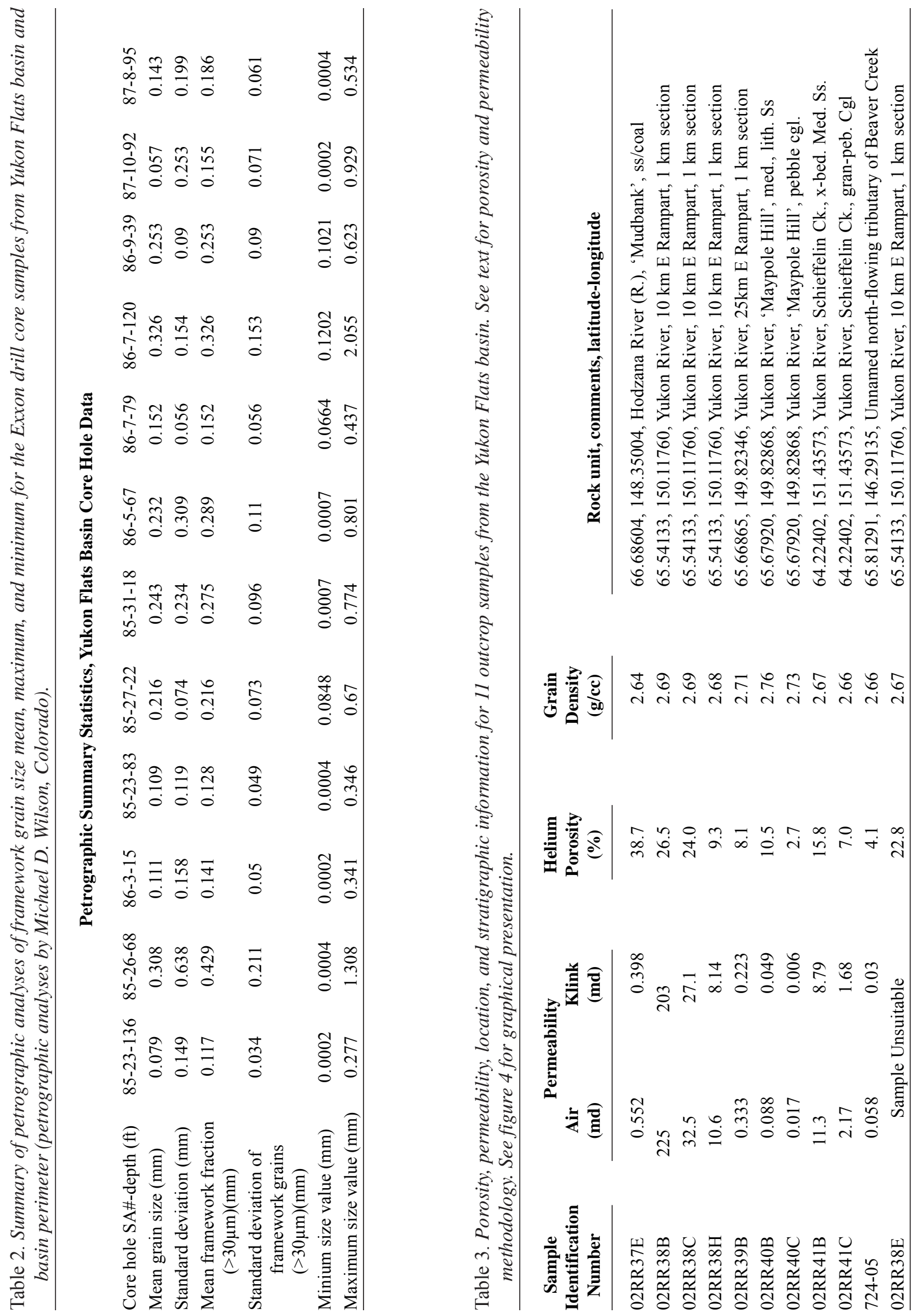


\section{YUKON FLATS CORE HOLE SAMPLES Folk QFL Diagram}

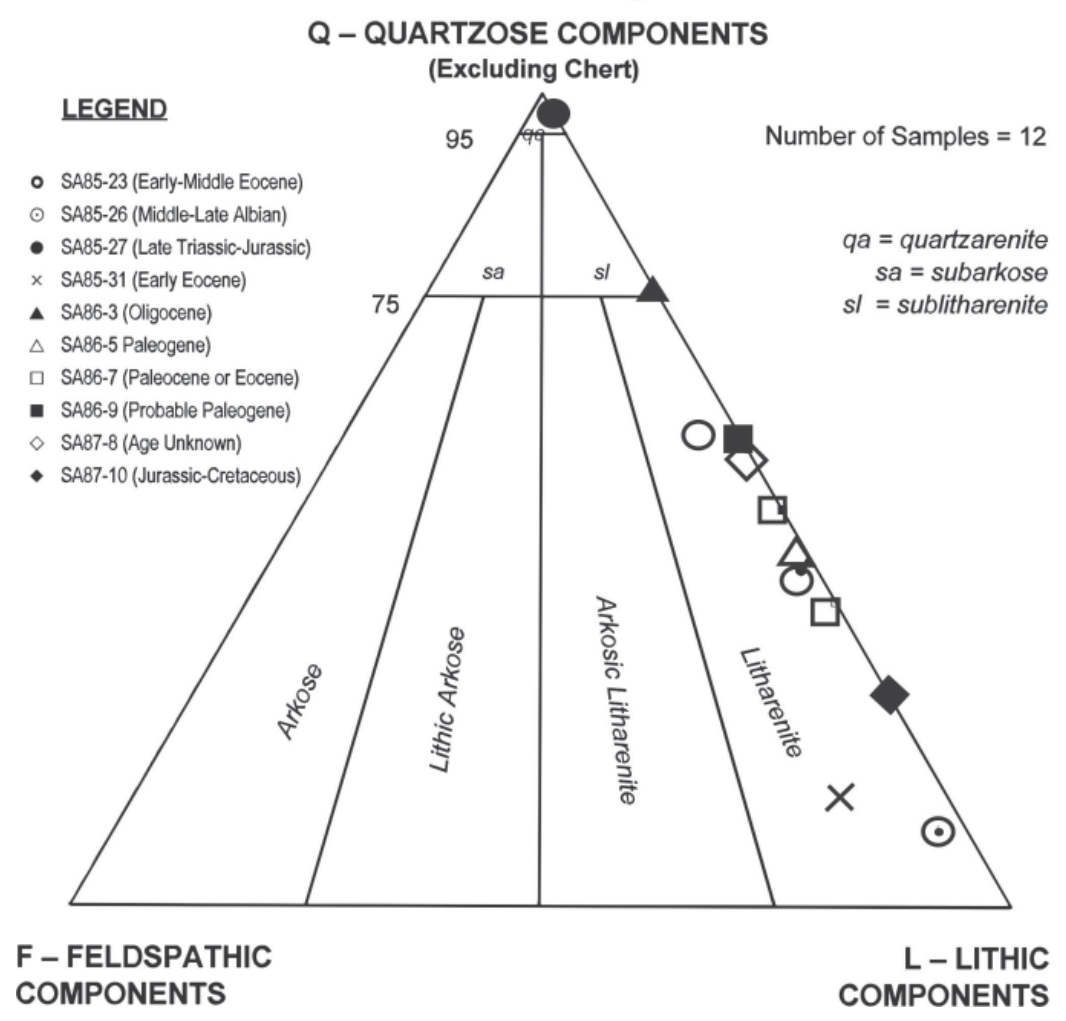

Figure 5. Quartz-Feldspar-Lithic Folk sandstone classification diagram, Yukon

resulting high degree of intergranular porosity reduction. In these sandstones with abundant ductile framework grains, intergranular porosity is reduced primarily by plastic grain deformation. Other means of porosity reduction in these sandstones include quartz and chert suturing, and siderite cementation. Photomicrographs in the appendix show some of these textural, grain size, and grain-boundary relationships.

Drew Mine drill core sandstone yields anomalously high permeability (154 md) and good porosity ( 7.7 percent; fig. 3, table 1). This sandstone was not selected for thinsectioning and petrographic examination. This was because most, though not all, core samples that were analyzed for petrophysics were cut for thinsection. Nonetheless, Drew Mine core yields high porosity and permeability and merits further investigation.

Maypole Hill drill core sandstone yields anomalously high porosity ( 11.7 percent) yet the permeability remains $<1$ millidarcy $(0.13 \mathrm{md})$ due to occlusion of pore throats. The mechanism of pore connectivity reduction in the Maypole Hill sandstone is most likely due to the alteration of mafic volcanic rock fragments that are common in the sandstone.
The vast majority of sandstone bodies visited during the field program yielded petrophysical analyses indicating fair to good potential reservoir quality. Similarly, these samples were reasonably quartz and chert rich (figs. 5-7). Therefore, the extrapolated reservoir characteristics for the Tertiary section of the Yukon Flats basin is here interpreted to be generally fair, with locally good reservoir quality. Based on the small number of pre-Tertiary age drill core sandstones analyzed for this study, hydrocarbon reservoir quality in the Yukon Flats basin margin is considered poor.

Sandstone reservoir viability is affected by grain size and grain-size distribution. Consequently these data were collected for drill core samples (table 2). One hundred framework grain size measurements were recorded from each drill core sandstone thinsection. Individual sandstone samples range from a framework grain size mean of $0.079 \mathrm{~mm}$ (very fine sand) to a grain size mean of $0.33 \mathrm{~mm}$ (medium sand). Eight of the 12 point-counted sandstone core samples are fine grained (0.125 to 0.25 $\mathrm{mm}$ ). Sandstone grain measurements and standard deviation are shown in table 2 . 


\title{
YUKON FLATS CORE HOLE SAMPLES Dickinson QmFLt Tectonic Setting Plot
}

\author{
Number of Samples $=12$
}

\section{Qm MONOCRYSTALLINE QUARTZ}

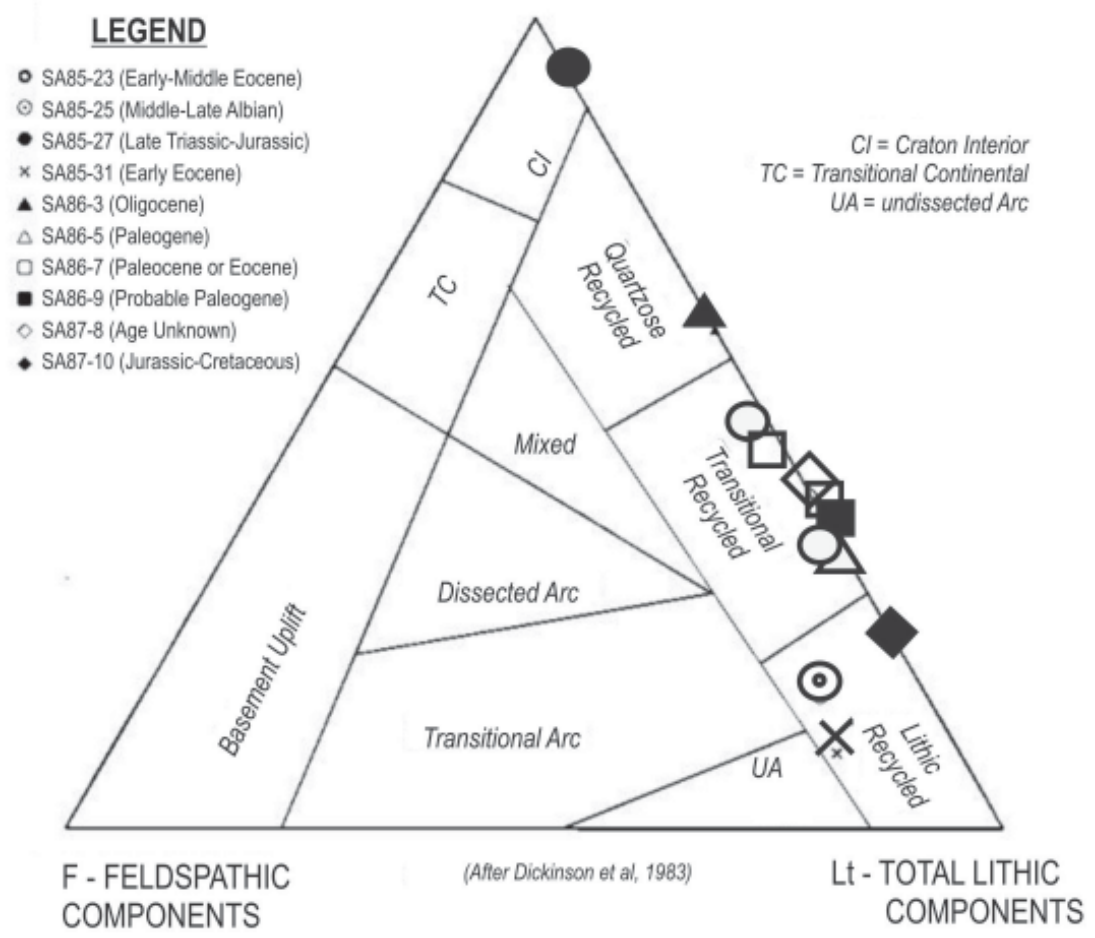

Figure 6. Tectonic setting plot [quartz-feldspar-lithic (includes chert)] of Yukon Flats basin core hole samples. Eleven of 12 sandstones plot in one of the 'Recycled' fields and one sandstone plots in the 'Craton Interior'field. This plot includes chert grains with the lithic components. The consequence is a significant shift toward the lithic pole of any chert-rich sandstone. When compared with figure 5 it graphically conveys the influence of the chert component relative to other lithic grains.

Chert is an abundant framework grain in several samples. The Jurassic- to Cretaceous-age Grayling Fork sandstone core contains 67 percent chert. The middle to late Albian age Eagle Trough sandstone includes 36 percent chert. The Paleocene age Preacher Creek sandstone includes 33 percent chert. The Bryant Creek sandstone includes 31 percent chert. The Early Eocene age Maypole Hill sandstone core includes 20 percent chert. The Oligocene(?) age Coal Creek sandstone includes 16 percent chert. Abundant chert in these samples suggests erosion of a recycled orogenic provenance or a transitional recycled provenance of the Dickinson and others (1983) classification (figs. 6 and 7).

Outcrop samples-Outcrops of the fluvial sandstone of the early Tertiary age basin fill were sampled during the several-day helicopter-supported field program. The localities where outcrop sandstones were collected are shown in figure 1 . Ten outcrop sandstones were analyzed for porosity and permeability, and 15 thinsections were examined petrographically.

Promising potential reservoir sandstones crop out just northeast of the town of Rampart. Here, along the Yukon River, a more than 1-km-thick stratigraphic section of probable Eocene age (Reifenstuhl and others, 1997b) includes thick, meandering stream deposits of sandstone, conglomerate, and coal. In outcrop, sandstone ranges from very light gray to nearly white, and from light brown to orange-brown. Sandstone is typically poorly sorted and contains up to 10 percent finely disseminated organic material. Polymictic conglomerate is up to $10 \mathrm{~m}$ 


\section{YUKON FLATS CORE HOLE SAMPLES Dickinson QmFLt Tectonic Setting Plot}

Number of Samples $=12$

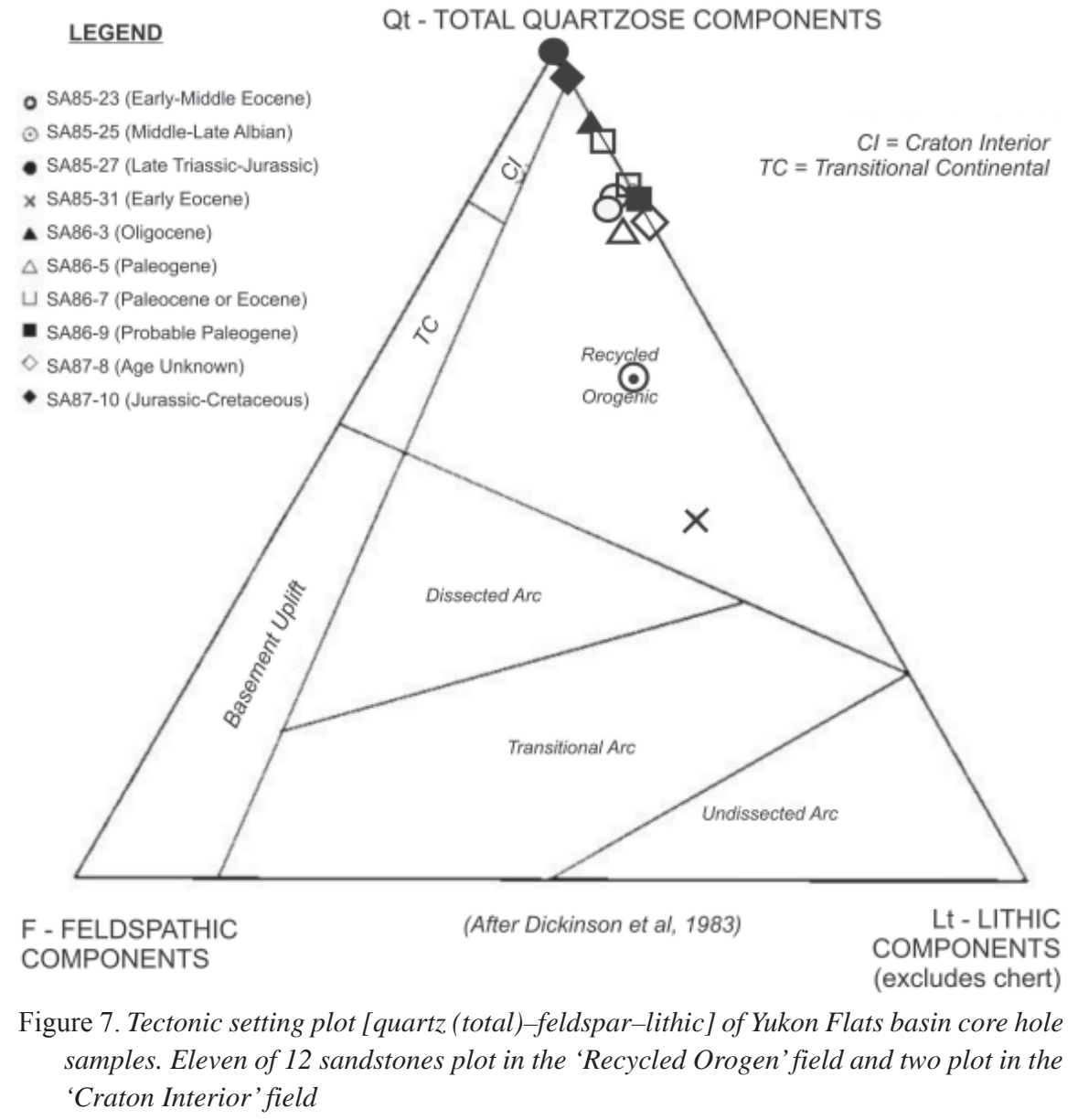

thick, locally cuts into sandstone and silty mudstone, contains less than 10 percent organic debris, with rare logs up to $1.5 \mathrm{~m}$ long and $20 \mathrm{~cm}$ in diameter. Coal beds are up to $10 \mathrm{~cm}$ thick and are a minor stratigraphic component. Coal grade appears to be lignite.

At Schieffelin Creek, on the Yukon River, several hundred meters of Eocene to Oligocene age fluvial sandstone, pebbly sandstone with lesser conglomerate, and minor coal are well exposed. These bedload-dominated braided stream deposits suggest good reservoir potential in outcrop, are stratigraphically similar to the Rampart locality, and yield good petrophysical characteristics (8.8 md and 15.8 porosity; fig. 4 ; table 3 ).

Sandstones from the Rampart and Schieffelin Creek localities are promising potential reservoirs due to relatively low ductile grain percentages and relatively high measured porosity and permeability (fig. 4; table 3). Ductile lithic grains constitute a significantly lower percentage at these outcrop localities relative to the Tertiary age drill core sandstones, and relative to sandstone at the Drew Mine, Maypole Hill, Bryant Creek, and Preacher Creek localities.

The sandstone at the 'mudbank' locality on the Hodzana River has impressive petrophysical results (fig. 4; table 3), but these clastic deposits are poorly lithified, poorly indurated, and of unknown age. Based on outcrop relationships, nature of organic material, and location within the basin, 'mudbank' sandstone, silty shale, and organic-bearing deposits are interpreted to be very young, and high in the stratigraphic section. Consequently 'mudbank'-equivalent stratigraphy is unlikely to be buried deep enough and in a position within a potential Yukon Flats basin petroleum system.

Geologic setting and source area of sandstone units-The tectonic provenance of the Yukon Flats basin sandstones is determined using models developed by Dickinson and Suczek (1979) and Dickinson and others (1983; figs. 6 and 7). These models have been applied to sandstones worldwide and to sandstone from other Alaska basins (Reifenstuhl and Reifenstuhl, 2003; 
Reifenstuhl and others, 1997a; Wartes and Reifenstuhl, 1997; Reifenstuhl, 1995; Reifenstuhl, 1991). The 12 point-counted drill hole samples from the Yukon Flats basin are erosional products of a provenance dominated by quartz-rich and chert-rich rocks, with lesser contributions from rocks that are quartz poor, such as shale, mafic and intermediate igneous rocks, and metamorphic rocks. One sample (from the Step Mountain area) indicates a strictly quartz-rich source (fig. 5). This quartz-rich sample is the Triassic- to Jurassic-age sandstone that crops out east of the Yukon Flats basin. This sandstone was derived from a craton interior (figs. 6 and 7).

Seven of the 12 point-counted drill core sandstones are volcaniclastic-rich (figs. 6 and 7) and Paleogene to Eocene age (table 1). These seven volcaniclastic litharenite sandstones were deposited during and after a time of documented, locally important continental rifting and bimodal volcanism in the Rampart area (Reifenstuhl and others, 1997b). This volcanism was probably related to crustal thinning and tectonism along the Tintina Fault system. Consequently, these mafic volcanic-rich sandstones of Paleogene to Eocene age record erosion of basalt and rhyolite uplands and are correspondingly rich in volcanic lithic fragments.

\section{CONCLUSIONS}

Summarizing all Yukon Flats basin petrophysical data using the qualitative terminology of North (1985), outcrop samples yield porosity that is negligible ( 2 samples), poor (3), fair (1), good (3) and permeability that is poor to fair (7), moderate (3); core sample porosity is negligible (15), poor (6) fair (2), and permeability is poor to fair (23).

To summarize the outcrop petrographic data: two distinct groups are evident and supported by the petrophysical results. Sandstones cropping out at Schieffelin Creek and northeast of Rampart are subarenite sandstone rich in quartz and chert, and relatively poor in ductile grains. These sandstones have a low percentage of volcanic rock fragments and their poreclogging alteration products. Sandstones at these Yukon River sections yield good reservoir characteristics as defined by porosity, permeability, and petrology. Conversely, sandstone outcrops at Maypole Hill and No Name Creek are litharenite sandstones with either abundant volcanic rock fragments or ductile lithic grains. Consequently, outcrop sandstones from Maypole Hill and No Name Creek yield poor reservoir characteristics.

Drew Mine drill core sandstone yields very high permeability $(154 \mathrm{md})$ and good porosity $(7.6 \%)$. No outcrop samples were analyzed for petrophysics from this locality. Petrographically Drew Mine sandstone is very poorly sorted, greenish dark gray litharenite sandstone, containing abundant volcanic rock fragment.
These characteristics suggest that it is unlikely to have good porosity or clear pore throats.

Viable reservoir characteristics are documented in sandstones from outcrops at Schieffelin Creek and northeast of the town of Rampart. Drew Mine drill core sandstone is not well constrained by the current reconnaissance data set. Additional sampling is required to understand the reservoir characteristics of sandstones at Drew Mine.

Drill core sandstones are from both basin fill, and basin margin stratigraphy. Generally the basin margin sandstones yield poor reservoir characteristics: low porosity, low permeability, high percentage of ductile, pore-filling framework grains, and quartz overgrowths. Siderite cementation commonly reduces pore space. Of the 23 drill core sandstones, only one has greater than 1 md permeability. Eighteen of the 23 drill core sandstones are of Tertiary age and, in any basin model or petroleum play model, must be considered to be Yukon Flats basin fill. The remaining five drill core sandstones are considered to be basin margin stratigraphy. Porosity values of the Tertiary age sandstone are generally better than that of basin margin sandstones (fig. 3; table 1). For example, six of the 18 Tertiary-age sandstones have more than 6 percent porosity. However, 22 of 23 drill core sandstones have less than $1 \mathrm{md}$ permeability.

\section{ACKNOWLEDGMENTS}

I thank Rick Stanley (U.S. Geological Survey) for reviewing an earlier version of this report. I also thank a second reviewer who requested anonymity.

\section{REFERENCES}

Decker, John, 1985, Sandstone modal analysis procedure: Alaska Division of Geological \& Geophysical Surveys Public-data File 85-3 p. 1-35.

Dickinson, W.R., 1970, Interpreting detrital modes of graywacke and arkose: Journal of Sedimentary Petrology, v. 40, p. 695-707.

Dickinson, W.R., and Suczek, C.A., 1979, Plate tectonics and sandstone compositions: The American Association of Petroleum Geologists, v. 63, no. 12, p. 2164-2182.

Dickinson, W.R., Beard, L.S., Brakenridge, G.R., Erjavec, J.L., Ferguson, R.C., Inman, K.F., Knepp, R.A., Lindberg, F.A., and Ryberg, P.T., 1983, Provenance of North American Phanerozoic sandstones in relation to tectonic setting: Geological Society of America Bulletin, v. 94, no. 2, p. 222-235.

Folk, R.L., 1974, Petrology of sedimentary rocks: Austin, Texas, Hemphill Publishing Company, $182 \mathrm{p}$

Kirschner, C.E., 1994, Interior basins of Alaska, in Plafker, G., and Berg, H.C., eds., The Geology of 
Alaska: Boulder, Colorado, Geological Society of America, The Geology of North America, v. G-1, p.469-493.

North, F.K., 1985, Petroleum geology: Unwin Hyman Inc, Winchester, Mass., 631 p.

Reifenstuhl, R.R., 1991, Gilead sandstone, northeastern Brooks Range, Alaska; an Albian to Cenomanian marine clastic succession, in Reger, R.D., ed., Short notes on Alaskan geology 1991: Alaska Division of Geological \& Geophysical Surveys Professional Report 111, p.69-76.

Reifenstuhl, R.R., 1995, Lithofacies, petrology, and petrophysics of the Kemik Sandstone (Lower Cretaceous), eastern Arctic Slope, Alaska, in Combellick, R.A., and Tannian, Fran, eds., Short notes on Alaska geology 1995: Alaska Division of Geological \& Geophysical Surveys Professional Report 117, p. 53-67.

Reifenstuhl, R.R., and Reifenstuhl, A.E., 2003, Preliminary petrographic study of 11 Mississippian to Tertiary age sandstones, Sagavanirktok Quadrangle, Brooks Range foothills and North Slope, Alaska, in Clautice, K.H., and Davis, P.K., eds., Short Notes on Alaska Geology 2003: Alaska Division of Geological \& Geophysical Surveys Professional Report 120, p. 71-81.

Reifenstuhl, R.R., Wilson, M.D., and Mull, C.G., 1997a, Petrography of the Tingmerkpuk Sandstone (Neocomian), northwestern Brooks Range, Alaska;
A preliminary study, in Clough, J.G., and Larson, Frank, eds., Short notes on Alaska Geology 1997, Recent research on Alaska geology: Alaska Division of Geological \& Geophysical Surveys Professional Report 118, p. 111-124.

Reifenstuhl, R.R., Dover, J.H., Pinney, D.S., Newberry, R.J., Clautice, K.H., Liss, S.A., Blodgett, R.B., Bundtzen, T.K., and Weber, F.R., 1997b, Geologic map of the Tanana B-1 Quadrangle, central Alaska: Alaska Division of Geological \& Geophysical Surveys Report of Investigations 97-15a, 17 p., 1 sheet, scale 1:63,360.

Scott, A.R., Tyler, Roger, and Clough, J.G., 1998, Exploration for coalbed methane in frontier regions using limited data: American Association of Petroleum Geologists 1998 annual meeting, Expanded Abstracts. (Illustration from accompanying presentation made at AAPG 1998 annual meeting, Salt Lake City, UT, May 17-20, 1998.)

Van der Plas, L., and Tobi, A.C., 1965, A chart for judging the reliability of point counting results: American Journal of Science, v.263, no. 1, p. 87-90.

Wartes, M.A., and Reifenstuhl, R.R., 1997, Preliminary petrography on the provenance of six Neocomian to Albian sandstones, northwestern Brooks Range, Alaska, in Clough, J.G., ed., Short Notes on Alaska Geology 1996: Alaska Division of Geological \& Geophysical Surveys Professional Report 118, p.131-140. 


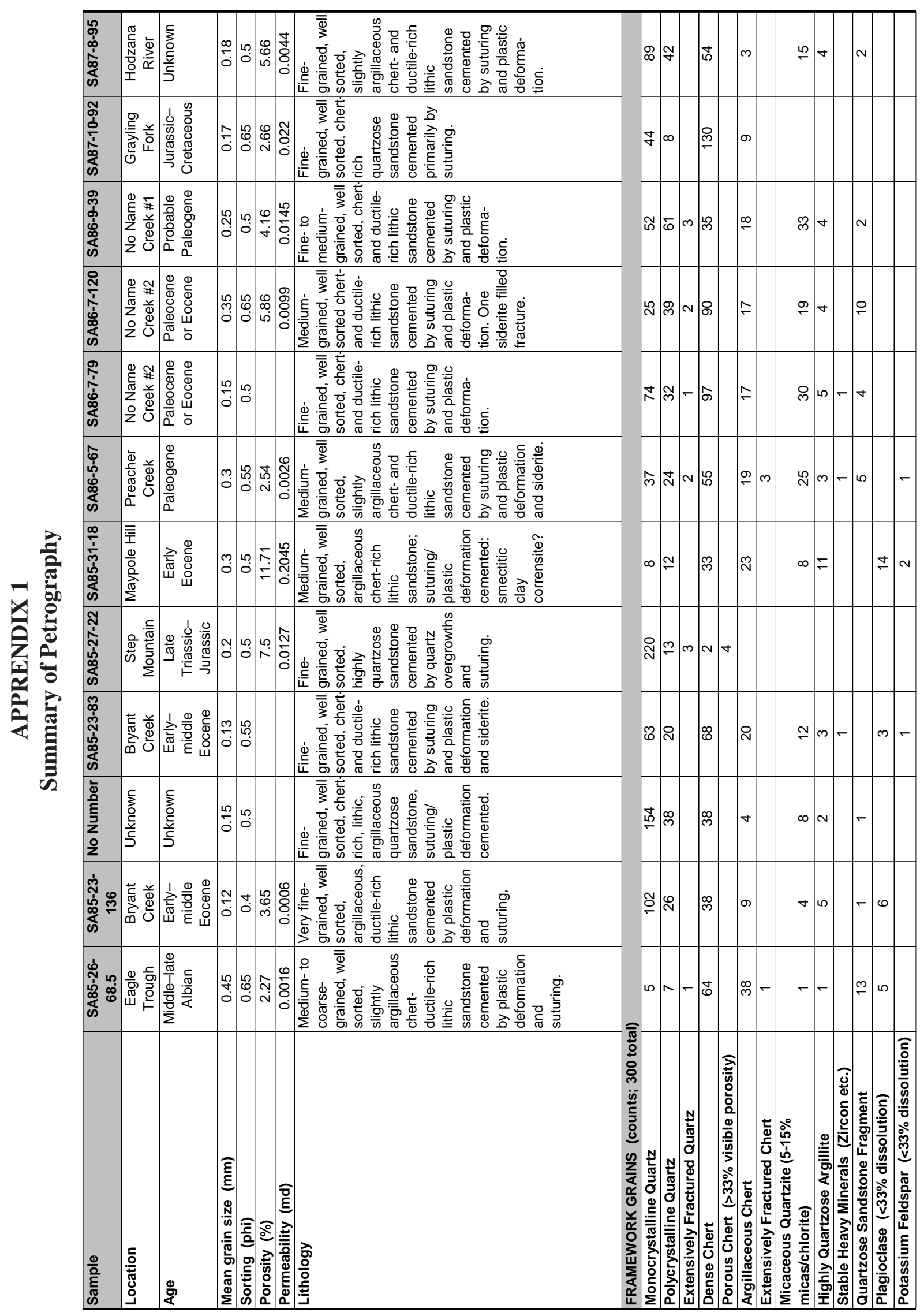




\begin{tabular}{|c|c|c|c|c|c|c|c|c|c|c|c|c|c|c|c|c|c|c|c|}
\hline 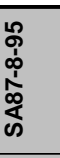 & & & & & & m & N & & $-\vec{\sigma} \mathrm{m}$ & & $\Lambda$ & & & & & $m=$ & & $\underset{-1}{\infty}$ & 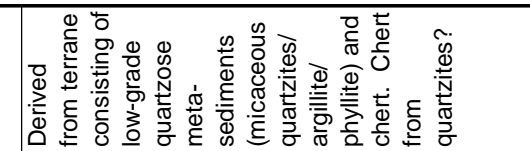 \\
\hline 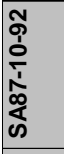 & & & -1 & & & & & $\sim$ & -1 & & & & & $m$ & N & $\checkmark \neg$ & & 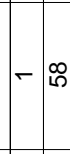 & 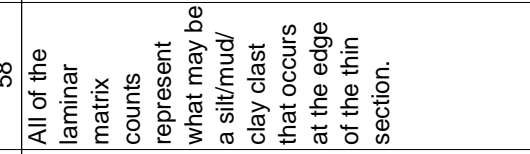 \\
\hline 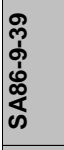 & & & -1 & & & & & $\sim \sim$ & $\exists \sim$ & & $\approx \mid-1$ & & & -1 & 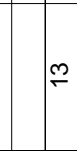 & 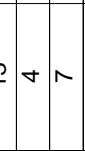 & -1 & & 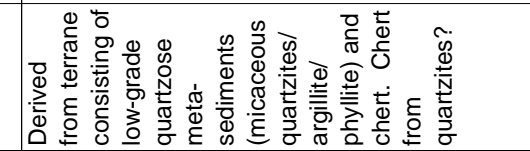 \\
\hline 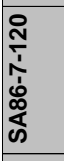 & & & & & & & $\sim \mathbb{N}$ & & $m$ & & $\exists$ & & & $\nabla$ & 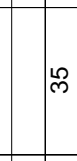 & $\sim$ & $\neg$ & & 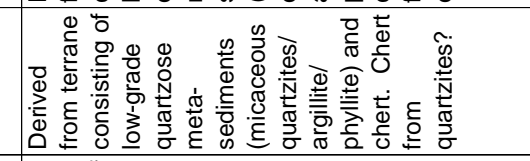 \\
\hline 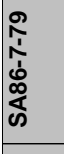 & & & & & & & o & & $\exists \mathrm{m}$ & & 0 & & & & ص & -1 & & & 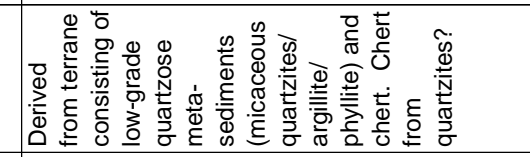 \\
\hline 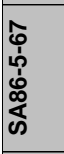 & & & $-1-1$ & & -1 & & $m \stackrel{\sim}{\sim}$ & & 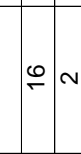 & & $\infty$ & & & & 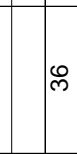 & & -1 & 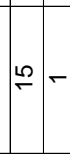 & 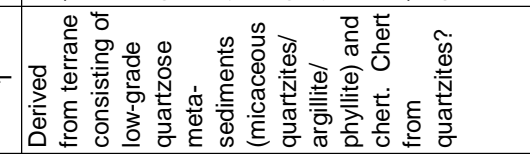 \\
\hline 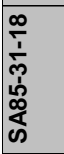 & 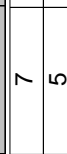 & & $\exists$ & $\stackrel{\sim}{s}$ & $\vec{a} \mid \wedge$ & $N$ & & & $n$ 궁 & $\begin{array}{ll}A & A\end{array}$ & $\nabla m$ & & & & $\infty \sim$ & & & ○) & 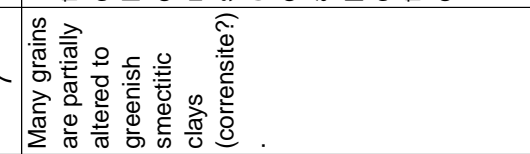 \\
\hline 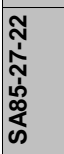 & & & & & & & & $N \sigma$ & & & & & $\nabla N$ & & & F & & N & 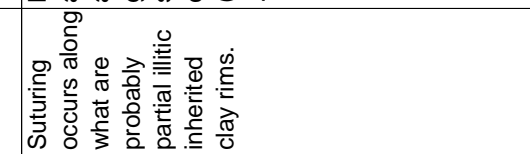 \\
\hline 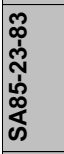 & & & -1 & & & & $\approx \stackrel{\rightarrow}{\rightarrow}$ & & 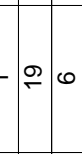 & $\nabla$ & & -1 & & -1 & A & -1 & & 의 & 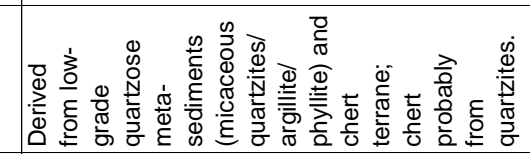 \\
\hline 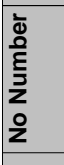 & & & & & -1 & & N & & $\begin{array}{lll}\infty & -1 \\
-1 & -1\end{array}$ & & & & & & & $\rightarrow \bumpeq$ & & 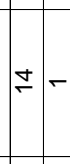 & 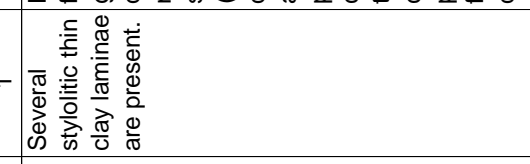 \\
\hline 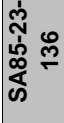 & -1 & & & & & & $\approx 0$ & & ని & & ब & & & & & $=\infty$ & & $\approx \sim$ & \\
\hline 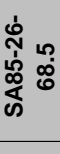 & $m \stackrel{\infty}{\sim}$ & 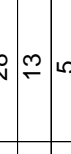 & & $\wedge \curvearrowleft$ & & & $\sim \approx \sim$ & & -1 & & | & & & $\sim$ & & & & $\approx$ & 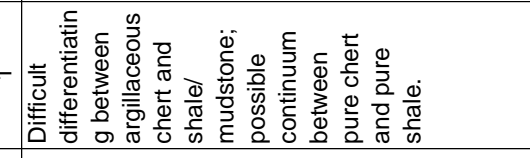 \\
\hline$\frac{0}{2}$ & 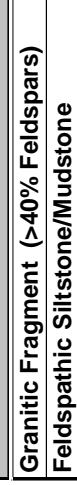 & 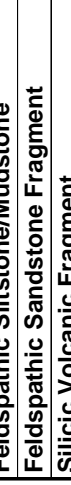 & 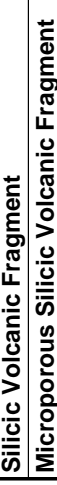 & 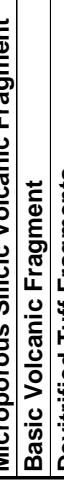 & & 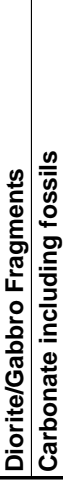 & 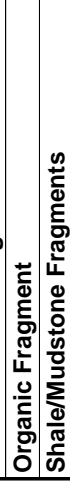 & 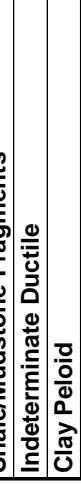 & : & 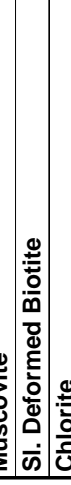 & 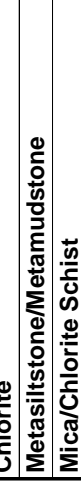 & 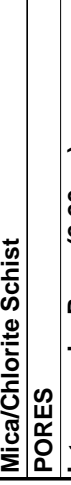 & 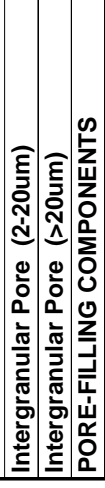 & 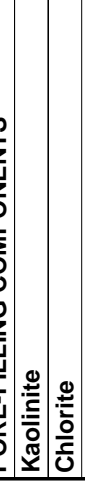 & 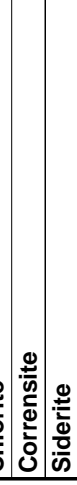 & 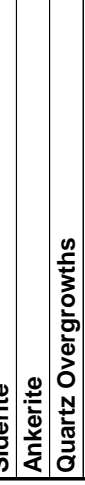 & 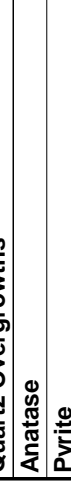 & 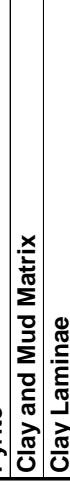 & 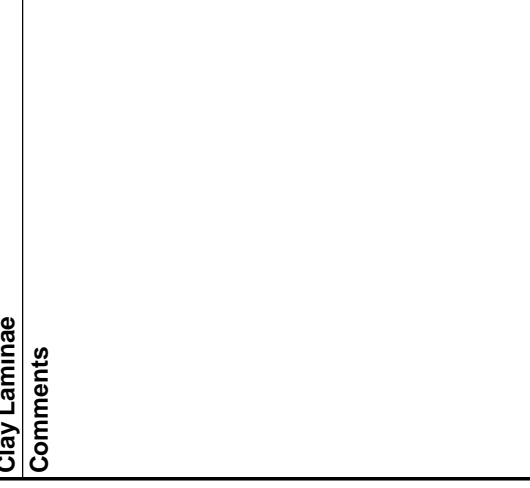 \\
\hline
\end{tabular}




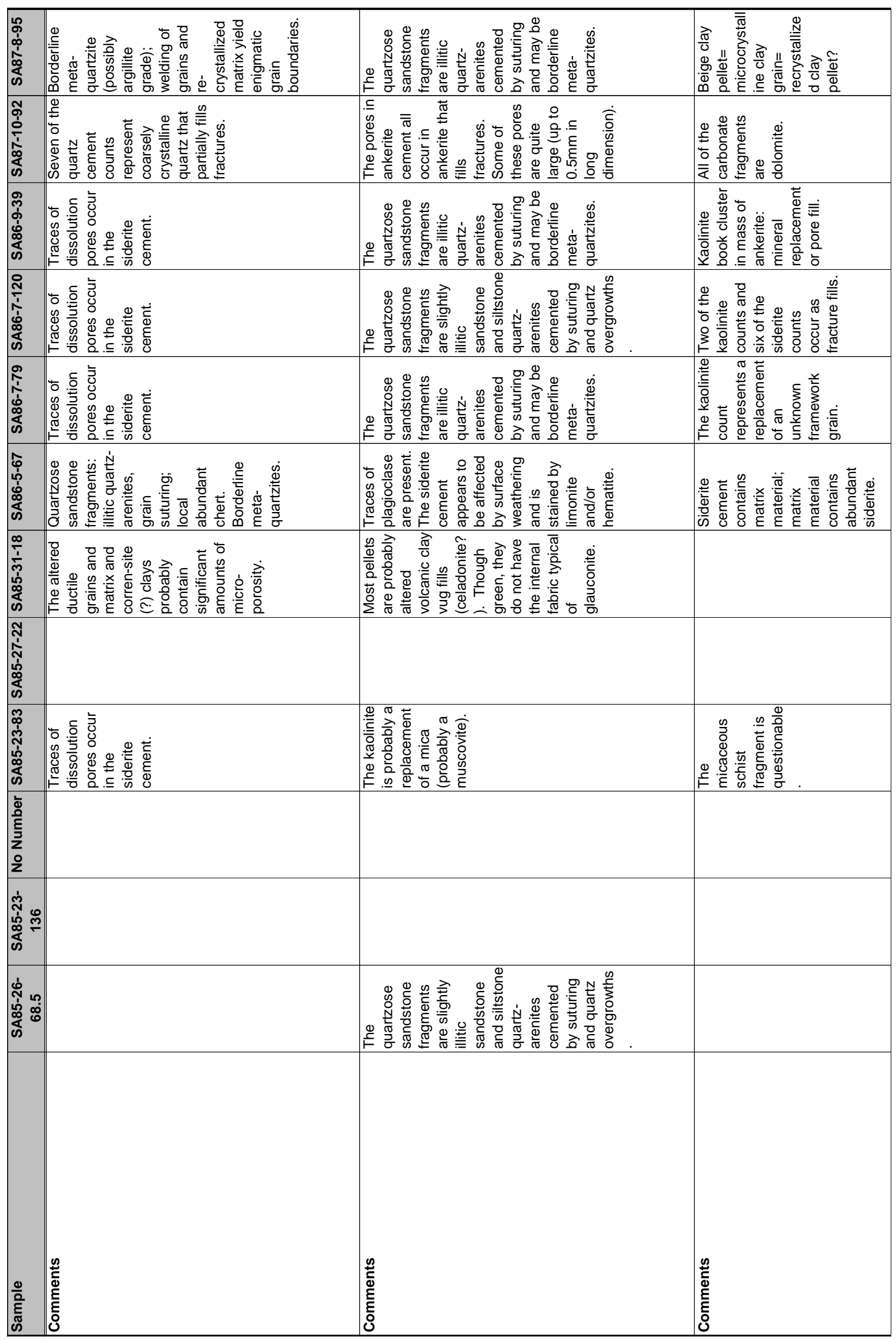


Report of Investigations 2006-1-Appendix 1

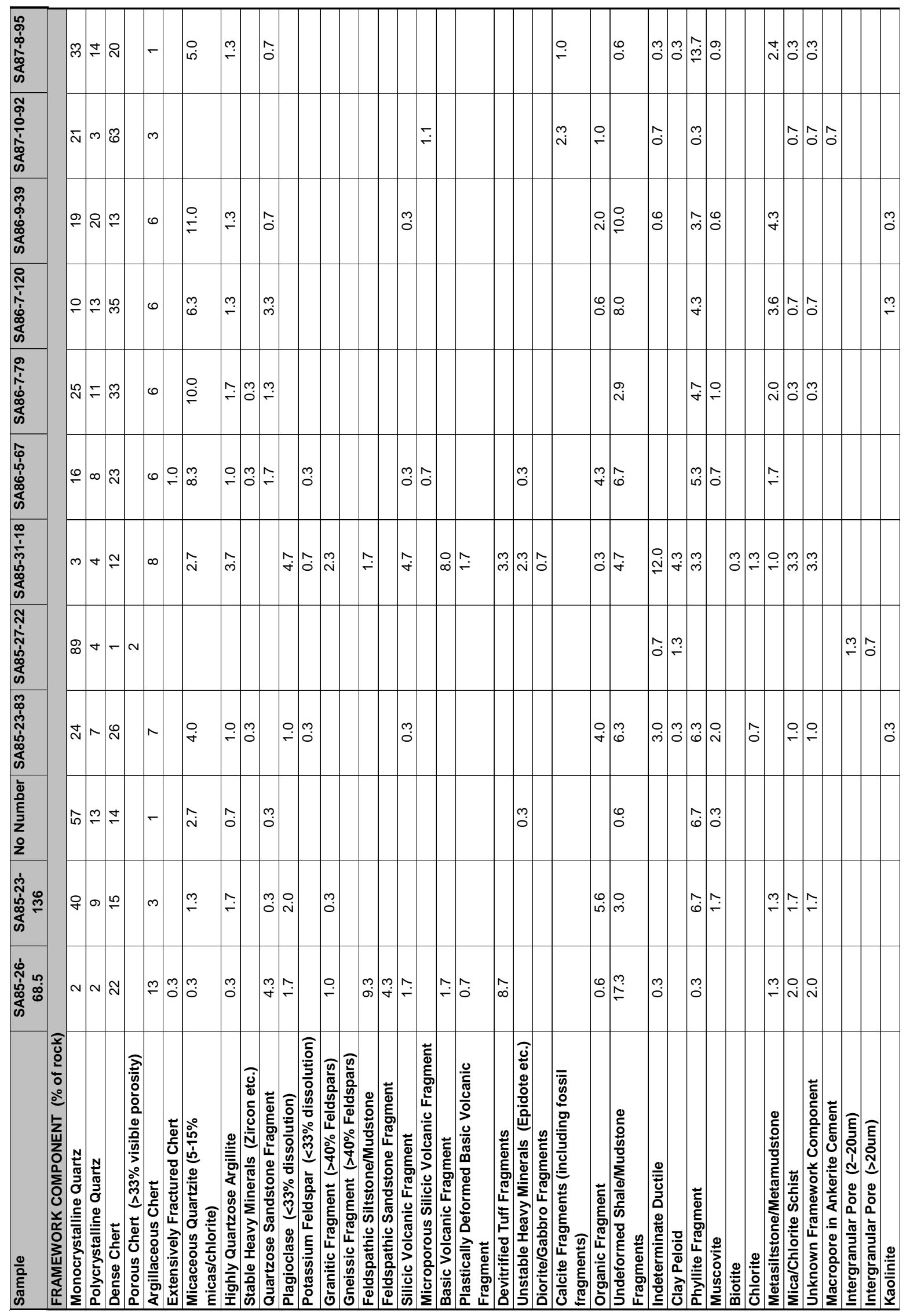


Yukon Flats Basin, Alaska: Reservoir characterization study

\begin{tabular}{|c|c|c|c|c|c|c|c|c|c|c|c|c|c|c|c|c|c|c|c|c|c|c|c|}
\hline 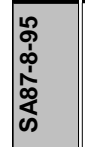 & & & $\stackrel{P}{\vec{i}} \overrightarrow{\dot{m}}$ & O. & $\stackrel{\infty}{\curvearrowright}$ & & $\hat{i}$ & 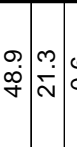 & & & & & & & & & & & 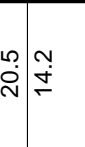 & $\stackrel{g}{i}$ & ä & 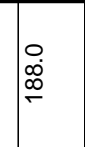 & \\
\hline 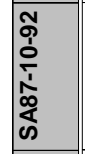 & $\mid \stackrel{\circ}{\rightarrow}$ & $\hat{0}$ & 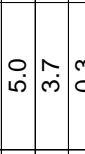 & $\stackrel{m}{\circ}: \stackrel{m}{0}$ & : & & $\left.\begin{array}{c}\infty \\
0 \\
0\end{array}\right)$ & ثี: & $\stackrel{\infty}{0}$ & & & & & & $\stackrel{n}{0}$ & $\stackrel{n}{0}$ & & 0 & 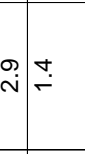 & $\stackrel{H}{A}$ & in & ब్ & \\
\hline 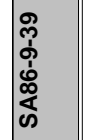 & & $\stackrel{m}{\dot{f}}$ & $\stackrel{m}{\rightarrow} \underset{\sim}{-} \stackrel{m}{\sim}$ & & $\stackrel{2}{2}$ & & $\underset{\sim}{\stackrel{-}{d}} \mathfrak{d}$ & 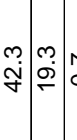 & & & & & & & O̊. & $\overbrace{0}^{\circ}$ & & : & & 它 & \& & ఊ্ণ & $\sim$ \\
\hline 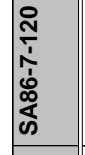 & & $\hat{\vec{i}}$ & $\hat{o}$ & & 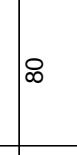 & & 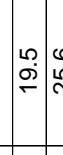 & 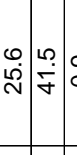 & ?ִ & & & & & & & & & & ه্] & $\begin{array}{l}0 \\
\dot{0}\end{array}$ & बे & $\stackrel{M}{\stackrel{M}{-1}}$ & -1 \\
\hline 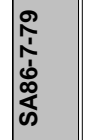 & & $\vec{i}$ & $\stackrel{m}{0}$ & & $\infty$ & & 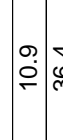 & 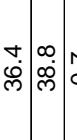 & $\hat{o}$ & & & & & & & & & & 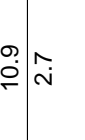 & $\mid \begin{array}{l}\infty \\
0 \\
0\end{array}$ & 8 & $\vec{N}$ & 0 \\
\hline 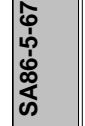 & & 守 & \begin{tabular}{|l|l}
$\hat{N}$ & $\hat{O}$ \\
0
\end{tabular} & 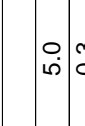 & $\begin{array}{r}n \\
\dot{n}\end{array}$ & $\stackrel{0}{0}$ & 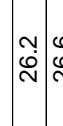 & 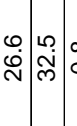 & $\stackrel{\infty}{\infty}$ & ণ & & $\overbrace{0}^{t}$ & & & $\stackrel{\infty}{0}_{0}^{\infty}$ & $\stackrel{\substack{\infty \\
0}}{0}$ & & 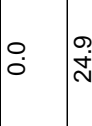 & & $\vec{F}$ & \& & $\vec{A}$ & o \\
\hline 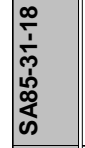 & & $\hat{\mathrm{N}} \hat{\dot{O}}$ & & $\stackrel{\circ}{i})$ & $\begin{array}{r}\vec{v} \\
\dot{v}\end{array}$ & 占 & 峦 & 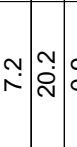 & $\ddot{0}$ & & ث. & {$[\hat{o}$} & $\ddot{\theta}_{0}^{\circ}$ & 守 & is & $\vec{G} \vec{G}$ & $\tilde{o}_{0}$ & $0_{0}^{+}$ & 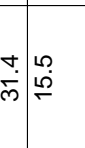 & 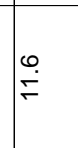 & $\hat{m}$ & $\tilde{\alpha}$ & \\
\hline 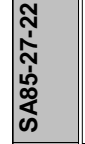 & & & $\dot{A}$ & $\hat{0}$ & $\infty$ & & $\stackrel{\sim}{\sim}$ & 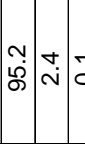 & -1:- & & & & & & & & & & ָָ & تָ & in & స్ & -1 \\
\hline 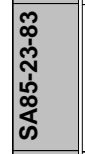 & & î́ & 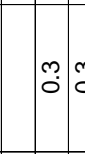 & $\begin{array}{c}m \\
\stackrel{m}{O}\end{array}$ & $\hat{\lambda}$ & in & 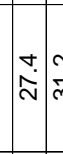 & 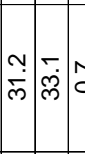 & $\hat{o}$ & 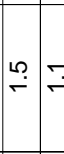 & $\vec{F}$ & $\overbrace{0}^{+}$ & $\stackrel{\infty}{0}_{0}^{\circ}$ & & $\overbrace{0}^{+}$ & ס̊ & & 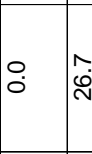 & 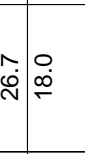 & बें & $\stackrel{d}{d}$ & 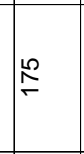 & \\
\hline 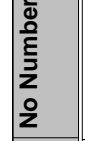 & & & \begin{tabular}{|c|c|c|}
$\stackrel{m}{o}$ & 0 \\
$\dot{\rho}$
\end{tabular} & $\hat{\dot{f}}$ & 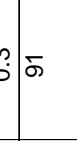 & & $\begin{array}{c}a_{0} \\
\infty\end{array}$ & 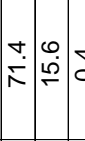 & ¿̊ & & & & & & & & & & $\begin{array}{lll}0 \\
0\end{array}$ & $\stackrel{g}{-i}$ & $\approx$ & స్ల & \\
\hline 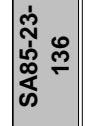 & & 它:? & 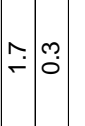 & $\stackrel{i}{r}$ & $\stackrel{5}{\circ}$ & $\stackrel{\infty}{\sim}$ & 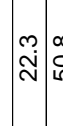 & 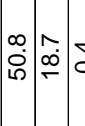 & $0_{0}^{0}$ & 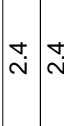 & ゙ָ & & $\stackrel{0}{-}$ & & & & & & تُ & $\dot{0}$ & $\tilde{\sim}$ & $\underset{-\overrightarrow{0}}{\overrightarrow{0}}$ & \\
\hline 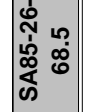 & $\hat{o}$ & & & 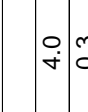 & $\dot{b} \vec{f}$ & $\begin{array}{l}0 \\
\stackrel{\sim}{A}\end{array}$ & 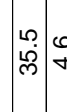 & \begin{tabular}{l|lll}
0 & -1 & 0 \\
$\dot{\sigma}$ & 0 & - & -
\end{tabular} & $\stackrel{0}{i}$ & & i & & $\stackrel{P}{\rightarrow}$ & I & $\stackrel{\infty}{\rightarrow}$ & 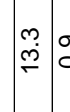 & $\ddot{\theta}$ & $\overbrace{0}^{0}$ & 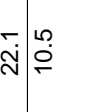 & $\vec{\sigma}$ & $\vec{\gamma}$ & $\vec{\Im}$ & $\sim$ \\
\hline 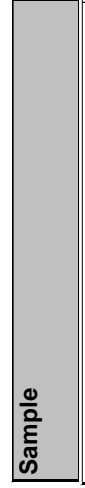 & 立 & 离 & 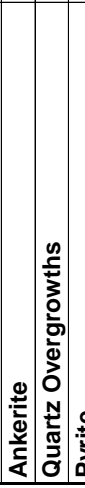 & 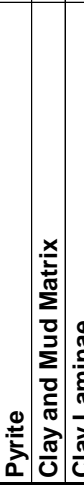 & 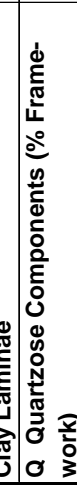 & 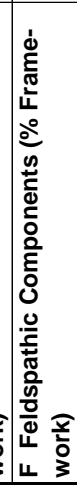 & 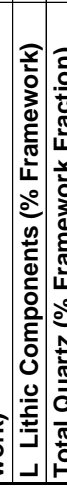 & 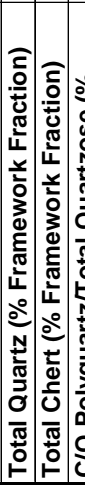 & 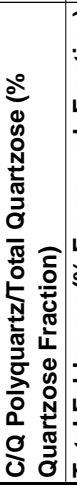 & 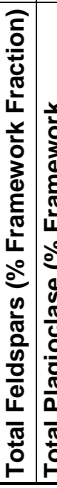 & 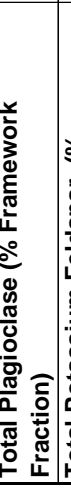 & 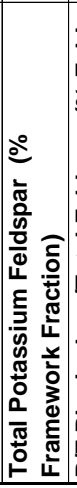 & 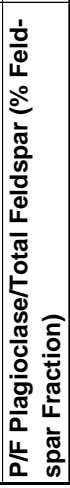 & 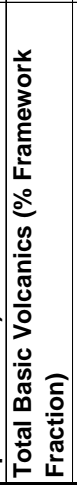 & 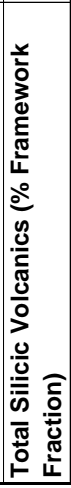 & 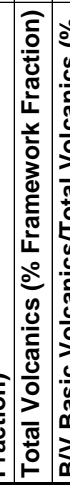 & 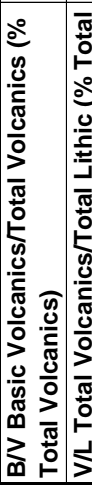 & 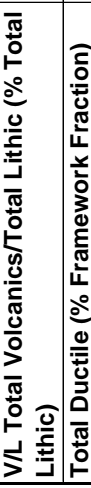 & 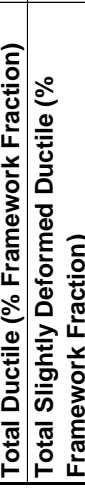 & 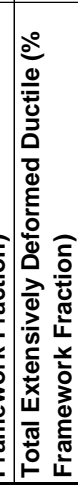 & 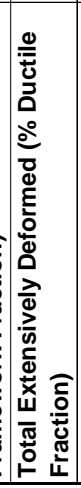 & 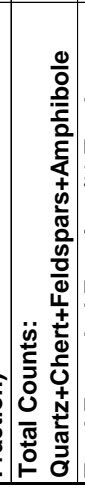 & 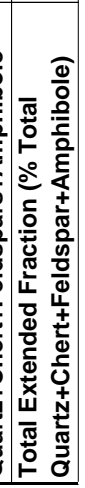 \\
\hline
\end{tabular}


Report of Investigations 2006-1-Appendix 1

\begin{tabular}{|c|c|c|c|c|c|c|c|c|c|c|c|c|c|c|c|c|c|c|c|c|c|}
\hline 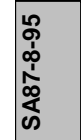 & 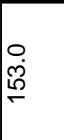 & $\begin{array}{l}n \\
\stackrel{n}{n}\end{array}$ & & $\mathcal{F}$ & ๕ & & ڤ & $\underset{\sim}{\oplus}$ & $\stackrel{+}{m}$ & & & $\vec{F}$ & $\stackrel{\overbrace{}}{\overbrace{}}$ & ఝ్ & $\sim$ & o & ১ু & ষ্ল & & & \\
\hline 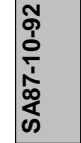 & 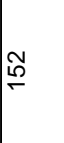 & $m$ & $\hat{o}$ & $\varnothing$ & q & $\wedge$ & is & $\nabla$ & & & & & 0 & 亗 & -1 & o & ڤ & $\underset{\sim}{\mathbb{N}}$ & & & \\
\hline 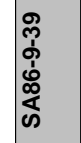 & $\stackrel{\Re}{\beth}$ & กิ & $\stackrel{0}{\circ}_{0}^{\circ}$ & $\stackrel{\infty}{q}$ & $\infty$ & $\sim$ & & | & م. & & & $\hat{o}_{0}$ & $\nabla$ & 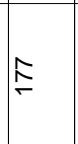 & $\sim$ & A & $\vec{\infty}$ & ঃ্ল & & & \\
\hline 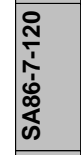 & $\stackrel{\infty}{\infty}$ & ల్ల & & $\stackrel{\infty}{\bullet}$ & ঃ্ন & & & هـ & $\stackrel{-1}{-1}$ & & & & んم & $\stackrel{\infty}{\sim}$ & & $\approx$ & $\infty$ & ஓ্ল & & & \\
\hline 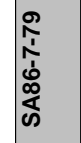 & $\stackrel{\infty}{\Im}$ & $\stackrel{\infty}{\infty}$ & & $\mathbb{E}$ & ঃ & & & $\exists$ & $\underset{m}{\stackrel{\Gamma}{*}}$ & & & $\underset{-i}{0}$ & んم & 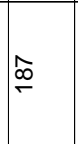 & N & ڤn & J & 各 & & & \\
\hline 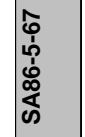 & 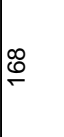 & $\prod_{m}^{\infty}$ & $\underset{\sim}{N}$ & $\overrightarrow{0}$ & ڤ & ڤ & & $\stackrel{\ominus}{\ominus}$ & مُ & & & 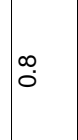 & $\Lambda$ & 足 & $m$ & $\stackrel{m}{\rightarrow}$ & 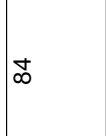 & 尽 & & & \\
\hline 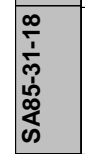 & I & $\vec{N}$ & 迥 & g & in & $\mathscr{q}$ & & t & $\stackrel{a}{\sim}$ & $\stackrel{n}{\sim}$ & & $\underset{-i}{\infty}$ & $\nabla$ & $\underset{్}{\stackrel{m}{-~}}$ & י্লি & $\exists$ & in & 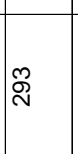 & 芦 & $\begin{array}{l}\dot{\sigma} \\
\stackrel{\leftrightarrow}{\sigma}\end{array}$ & \\
\hline 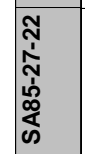 & $\tilde{\neg}$ & ळ్ల & & $\overrightarrow{0}$ & م) & & & ڤ & & & & & & $\stackrel{\infty}{\sim}$ & & $\widehat{F}$ & $\infty$ & 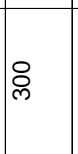 & & & \\
\hline 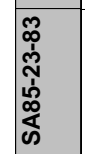 & 点 & $\stackrel{\sim}{ }$ & $\stackrel{0}{\circ}$ & 尺 & ৪ & $\rightarrow$ & & $\infty$ & & & & 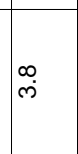 & $\infty$ & $\underset{\sim}{\widetilde{-}}$ & $\wedge$ & 路 & 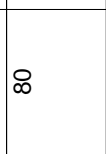 & 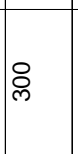 & $\stackrel{\vec{m}}{\text { p. }}$ & 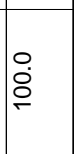 & \\
\hline 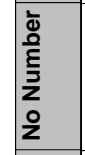 & | & กิ & & $\stackrel{\infty}{q}$ & 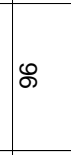 & $\nabla$ & & $\underset{\neg}{\triangleleft}$ & $0_{0}^{t}$ & & & $\left.\right|_{0} ^{+}$ & $\wedge$ & $\underset{-1}{\stackrel{0}{0}}$ & $\rightarrow$ & $\sim$ & $\hat{a}$ & 尽 & & & \\
\hline 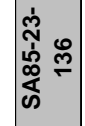 & ס्ञ & ๒ & & 埚 & ৪্ণ & & & 웅 & $\stackrel{i}{i}$ & $0_{0}^{+}$ & & $\mid \vec{i}$ & $\infty$ & $\underset{\exists}{\infty}$ & م & $\infty$ & $\widehat{\infty}$ & $\stackrel{\infty}{\stackrel{\infty}{N}}$ & $\stackrel{\circ}{\circ}$ & 总 & \\
\hline 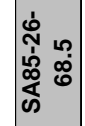 & 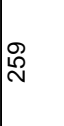 & $\nabla$ & 突 & $\vec{\infty}$ & $\tilde{0}$ & $\infty_{m}^{\infty}$ & & $\sim$ & i̊ & $\vec{F}$ & & & -1 & $\underset{\sim}{\mathbb{N}}$ & (요 & ని & $\stackrel{\leftrightarrow}{\circ}$ & 尽 & $\mid \begin{array}{l}0 \\
\infty \\
\infty\end{array}$ & 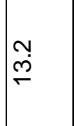 & \\
\hline 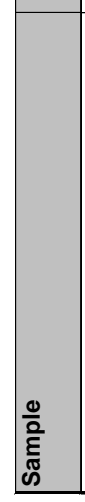 & 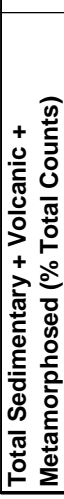 & 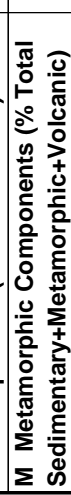 & & 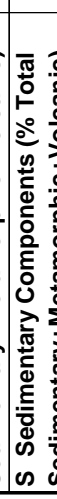 & 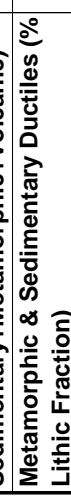 & 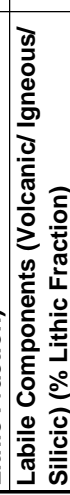 & 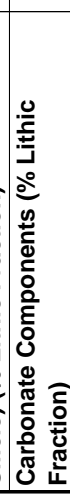 & 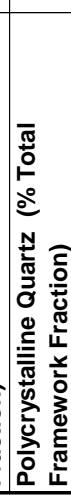 & 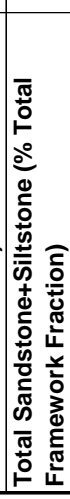 & 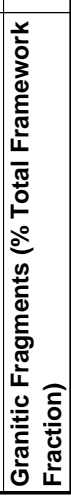 & 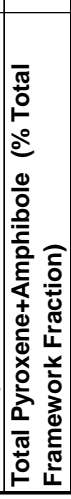 & 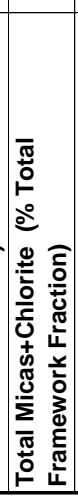 & 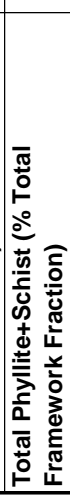 & 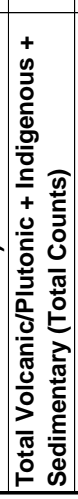 & 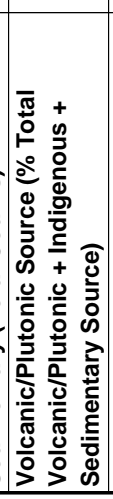 & 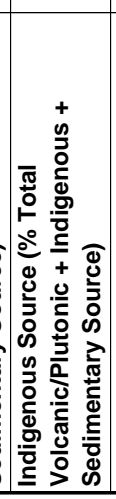 & 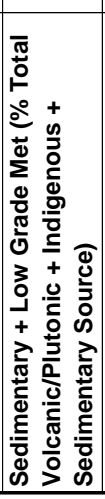 & 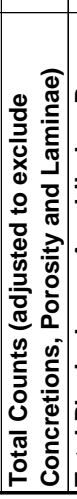 & 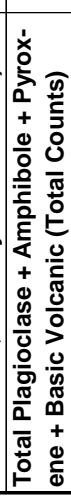 & 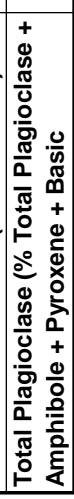 & 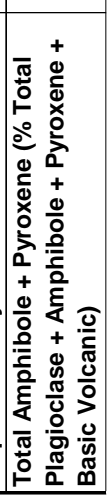 \\
\hline
\end{tabular}




\begin{tabular}{|c|c|c|c|c|c|c|c|c|c|c|c|c|c|c|c|c|c|c|}
\hline 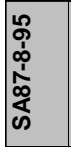 & & 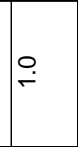 & & & F & $\stackrel{\circ}{\circ}$ & & & & & & $m$ & 总 & & $\exists$ & $\tilde{\sim}$ & m) & $\stackrel{\infty}{\infty}$ \\
\hline 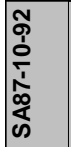 & & $\stackrel{\circ}{\stackrel{\rho}{r}}$ & & $\stackrel{N}{N}$ & ָָ & $\overbrace{0}^{+}$ & ơ & 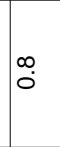 & 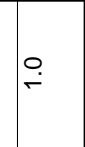 & $\stackrel{O}{\rightarrow}$ & ஹ̊. & iे & œ & $\stackrel{\overbrace{}}{\oplus}$ & $\exists$ & $\tilde{N}$ & 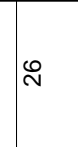 & $\hat{m}$ \\
\hline 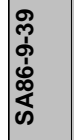 & & $\hat{\omega}$ & & $\overbrace{0}^{\infty}$ & $\hat{\infty}_{\infty}$ & & & & & & & $\stackrel{\infty}{\rightarrow}$ & बे & 0 & $\sigma$ & న & $\tilde{m}$ & $\prod_{m}^{\infty}$ \\
\hline 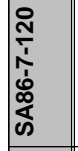 & & $\hat{F}$ & & $\stackrel{m}{\rightarrow}$ & 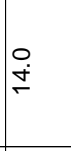 & & & & & & & m) & ৪ & 요 & $\exists$ & $\stackrel{m}{\sim}$ & $\tilde{N}$ & $\hat{m}$ \\
\hline 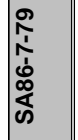 & & $\vec{i}$ & & & ì & & & & & & & L & ঃㄱ & & N & 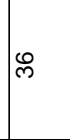 & $\hat{m}$ & $\stackrel{\infty}{\infty}$ \\
\hline 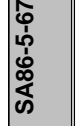 & & 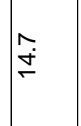 & & & 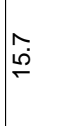 & ம் & $\tilde{0}$ & & $\stackrel{-1}{0}$ & "). & @̊ & J & ঃㄱ & & సี & F & $\tilde{N}$ & m \\
\hline 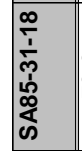 & $\mid \begin{array}{l}0 \\
0 \\
\end{array}$ & $\hat{o}$ & & $\hat{N}$ & 㐫 & $\stackrel{\circ}{\text { N }}$ & $0_{0}^{-1}$ & & ${ }_{0}^{-1}$ & to & @̊) & ㄱ & ฉి & ळ & ڤ & 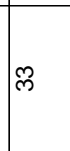 & बे & $\prod_{m}^{\infty}$ \\
\hline 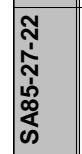 & & & & & $\dot{A}$ & $\hat{o}$ & $\stackrel{\bullet}{\circ}$ & $\stackrel{i}{\mathrm{~N}}$ & $\stackrel{n}{0}$ & $\stackrel{L}{N}$ & $\overrightarrow{\text { A }}$ & & & & 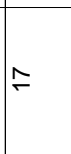 & $\tilde{N}$ & $\stackrel{\mathscr{N}}{\sim}$ & $\stackrel{\infty}{\infty}$ \\
\hline 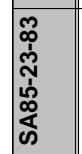 & & $\hat{\omega}$ & & $\stackrel{m}{0}$ & $\mid \hat{0}$ & 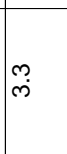 & & & & & & $\stackrel{\infty}{-1}$ & ब & 0 & 궁 & $\stackrel{\infty}{\sim}$ & $\vec{m}$ & $\prod_{m}^{\infty}$ \\
\hline 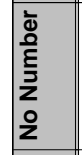 & & $\stackrel{m}{0}_{0}^{m}$ & & & is & $\widehat{\alpha}$ & & & & & & -1 & ஓ্ণ & & ㄱ & $\stackrel{\infty}{\sim}$ & $\vec{m}$ & $\infty_{\infty}^{\infty}$ \\
\hline 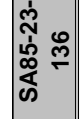 & & ז & & & 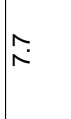 & $\stackrel{r}{i}$ & & & & & & $\approx$ & : & & 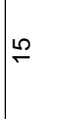 & $\stackrel{\sim}{N}$ & $\tilde{\sim}$ & $\infty_{m}^{\infty}$ \\
\hline 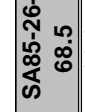 & & & & $\hat{o}$ & $\hat{0}$ & $\stackrel{\circ}{\dot{\sigma}}$ & & & & & & N & & 足 & ん & $\tilde{m}$ & बे & $\hat{m}$ \\
\hline 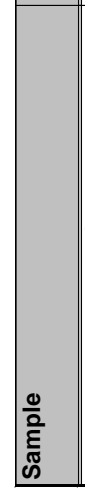 & 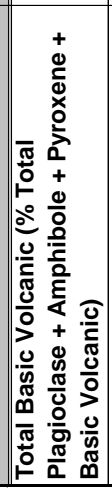 & 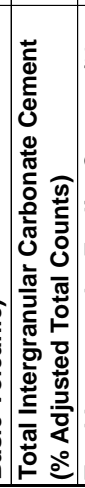 & 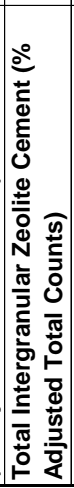 & 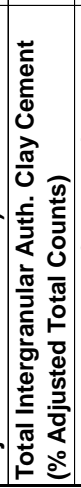 & 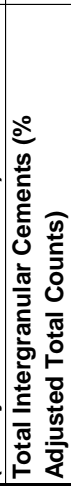 & 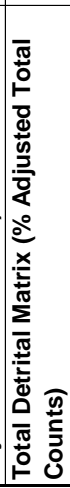 & 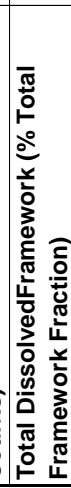 & 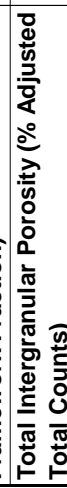 & 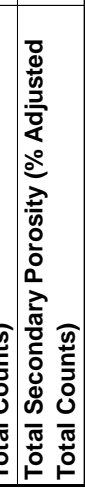 & 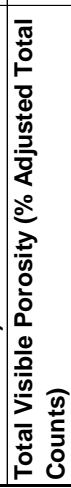 & 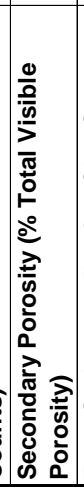 & 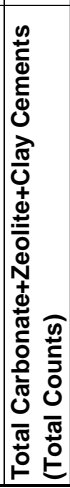 & 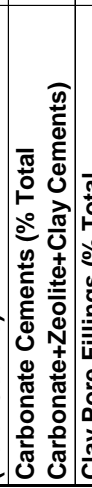 & 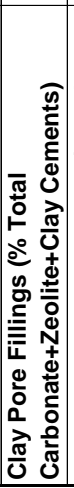 & 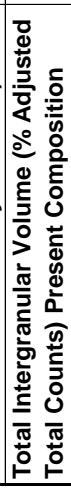 & 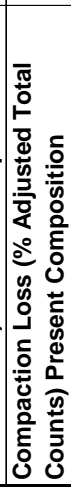 & 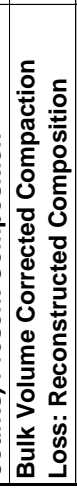 & 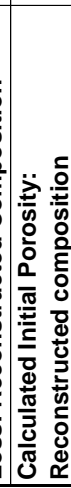 \\
\hline
\end{tabular}




\section{APPENDIX 2 Yukon Flat basin and basin perimeter drill core photomicrographs}

Photomicrographs of Yukon Flats basin sandstone thinsections from the Exxon shallow drill hole program are basin fill and basin-perimeter bedrock.

Abbreviations used and photomicrograph caption format:
Locality information, creek or physiographic drill core site name;
Number of core hole (\#2, for example, if two core holes were drilled at a
Number of core hole (sequentially in the Exxon Yukon Flats basin drillin
Year core drilling took place (for example, 1986);
Depth of core sample in feet;
Age, where known;
PL (plane light);
XP (crossed polarizers);
Magnification (40X or $100 \mathrm{X}$ for example, for a 4 inch by 6 inch image)

Bluish-gray or blue area in photomicrographs is porosity, which has been filled with epoxy during sample preparation. Porosity has been reduced during the rock's burial and compaction by deformation of the ductile shale, phyllite, and metamorphic grains. Also, dissolution of silica from quartz and chert has decreased porosity locally.

A summary of the porosity and permeability data from the 24 Yukon Flats basin margin drill cores includes porosity of 1.1 to 11.7 percent (average about 4 percent) and permeability of 0.001 to 171.3 md (average about 0.4 md; fig. 3; table 1). In summary, this small sample number (24) of basin and basin-margin sandstones analyzed for porosity and permeability indicates generally poor petrophysical characteristics for hydrocarbon reservoirs (see text for details).

Compositionally, Yukon Flats basin perimeter drill core samples range from litharenite sandstone (10 samples), sublitharenite sandstone (1 sample) to quartzarenite sandstone (1 sample; fig. 5).

Sandstone reservoir viability is affected by grain size and grain-size variability, consequently these data were collected for drill core samples. One hundred framework grain-size measurements were recorded from each drill core sandstone thinsection. Individual sandstone samples range from a framework grain size mean of $0.079 \mathrm{~mm}$ (very-fine sand) to a grain size mean of $0.33 \mathrm{~mm}$ (medium sand). Eight of the 12 point-counted sandstone core samples are fine grained $(0.125$ to $0.25 \mathrm{~mm})$. Sandstone grain measurements and standard deviation are shown in table 2 .

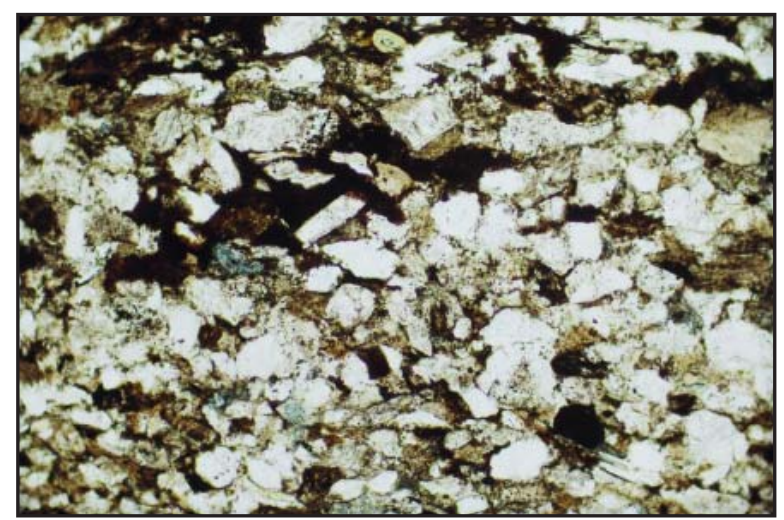

No Name Creek \#2, SA Corehole 7, 1986-120, Paleocene or Eocene, PL, 40X. Medium-grained, well sorted chert- and ductile-rich lithic sandstone cemented by suturing and plastic deformation. A shear zone containing some finely crystalline siderite occurs at the left edge of the view. Point-counted visible porosity is 0 percent; chert is abundant (42 percent) as are ductile grains (19 percent).

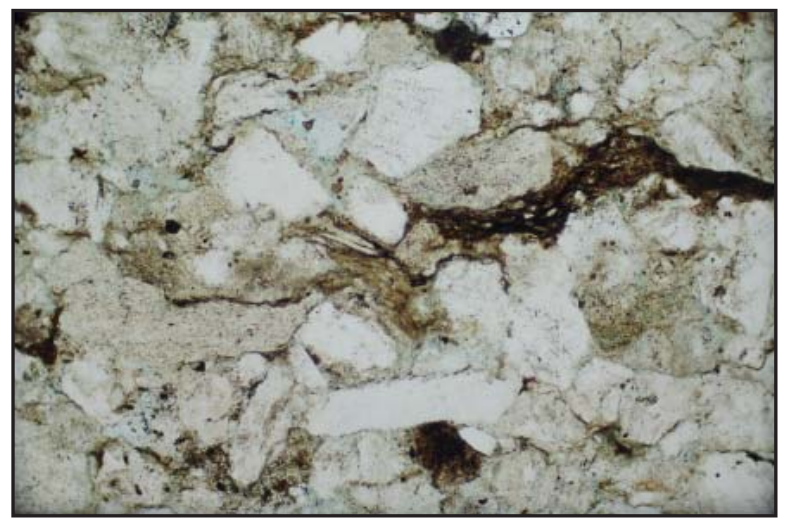

No Name Creek \#2, SA Corehole 7, 1986-79, Paleocene or Eocene, PL, 100X. The major agents of porosity destruction in this sandstone are suturing and plastic deformation of ductile grains. A trace of visible porosity occurs in a cluster of kaolinite at the upper left and a crystal of siderite is present within this mass of authigenic clay. 


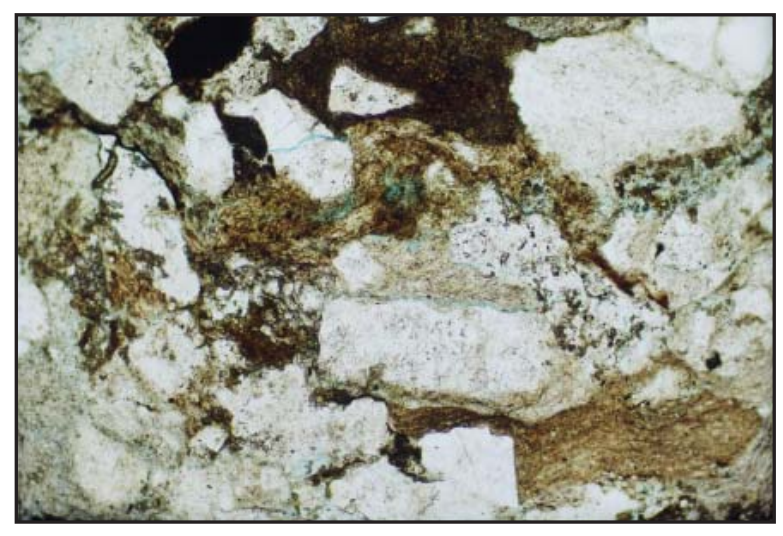

No Name Creek \#2, SA Corehole 7, 1986-120, Paleocene or Eocene, PL, 100X. All visible porosity has been eliminated by a combination of plastic deformation, suturing of chert, and siderite infill. A highly deformed phyllite is at center of view; a very finely crystallized siderite mass occurs just above. The siderite may infill or mask an argillaceous grain or a mass of matrix material.

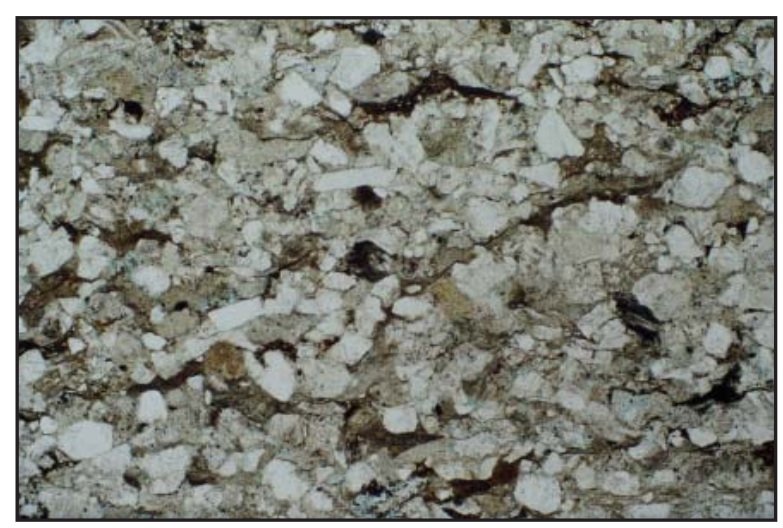

No Name Creek \#2, SA Corehole 7, 1986-79, Paleocene or Eocene, PL, 40X. Fine-grained, well sorted chertand ductile-rich lithic sandstone cemented by suturing and plastic deformation. Point-count measured visible porosity is 0 percent. Quartz (36 percent), chert (38 percent), and ductile grains (11 percent) are the dominant components.

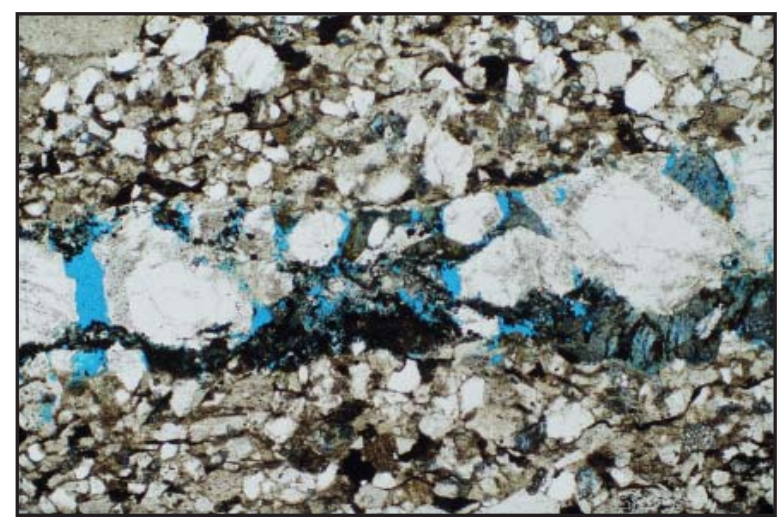

Grayling Fork, SA Corehole 10, 1987-92, JurassicCretaceous, PL, 40X. This sample is a fine-grained, well sorted, chert-rich, quartzose sandstone cemented primarily by suturing. A trace of point-count measured porosity (1 percent) occurs in this sample. Chert is very abundant in this sandstone (67 percent).

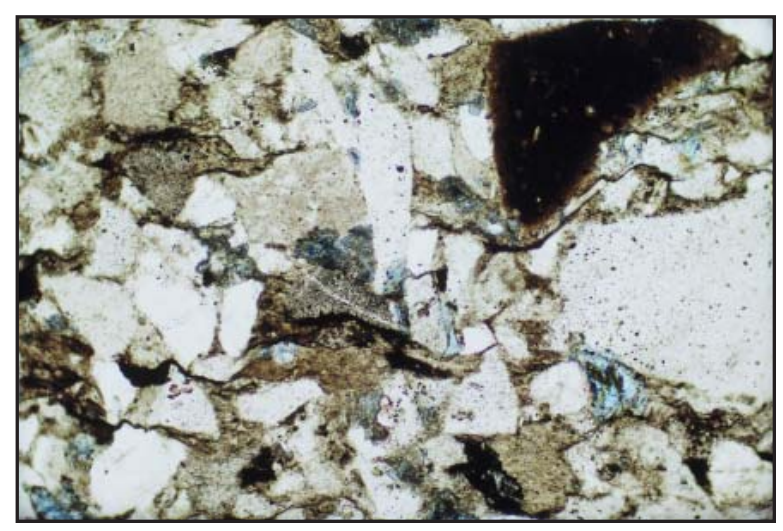

Grayling Fork, SA Corehole 10, 1987-92, JurassicCretaceous, PL, 100X. Visible porosity in this chertrich sandstone is virtually nil due to a combination of suturing, quartz overgrowths (4 percent), and ankerite cement (5 percent)(stained pale blue). 


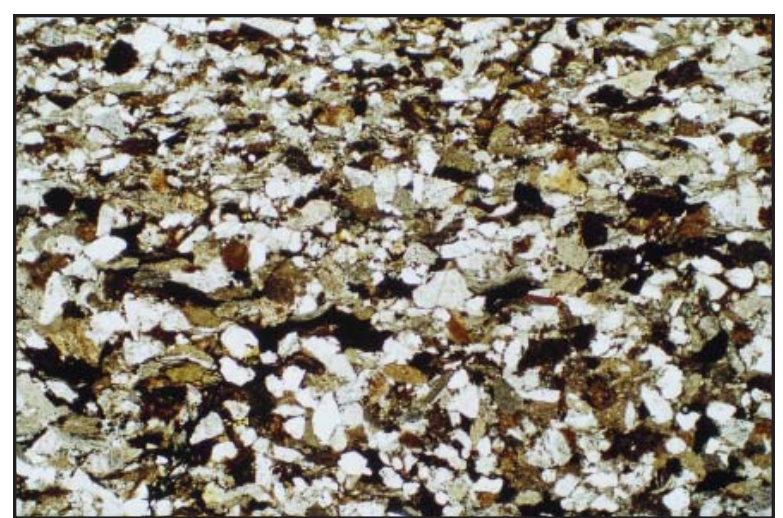

Bryant Creek, Corehole 23, 1985-83, age?, PL, 40X. Fine-grained, well sorted chert- and ductile-rich lithic sandstone cemented by suturing and plastic deformation and siderite. Point-count measured porosity in this sandstone is 0 percent. Quartz (31 percent), chert (33 percent), and ductile grains ( 26 percent; primarily shale, mudstone, argillite, and phyllite fragments) are major framework components.

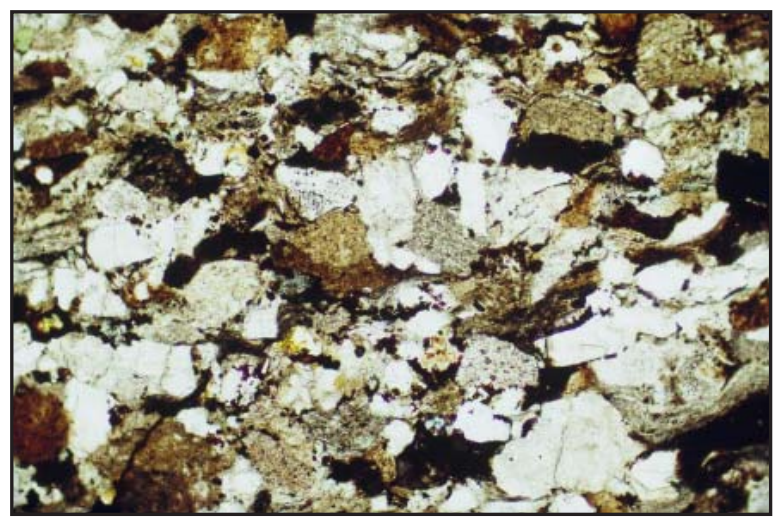

Bryant Creek, Corehole 23, 1985-83, age?, PL, 100X. The lack of visible porosity in this sandstone is primarily attributable to plastic deformation of ductile grains, suturing, and siderite cement ( 6 percent). The latter has been partially altered to hematite (dark reddish-brown to black).

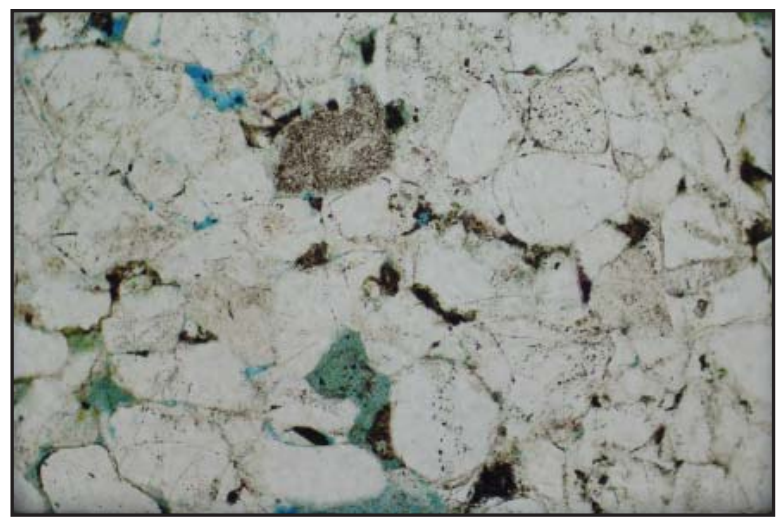

Step Mountain, Corehole 27, 1985-22, Late Triassic to Jurassic, PL, 100X. Quartz overgrowths (15 percent) and compaction loss by suturing and minor plastic deformation (21 percent uncorrected for changes in bulk volume) are the major agents of porosity loss. The pale green grain at the center-bottom of view may be an altered glauconite pellet.

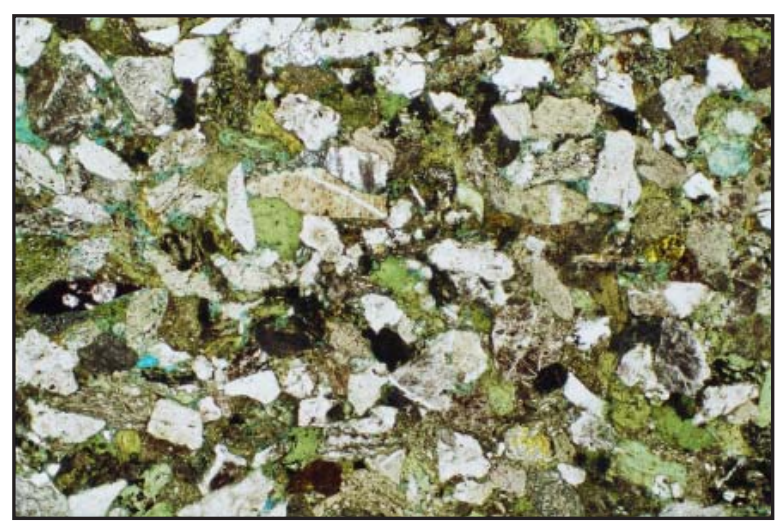

Maypole Hill, Corehole 31, 1985-18, Early Eocene, PL, 40X. Medium-grained, well sorted, slightly argillaceous, chert-rich lithic sandstone cemented by suturing and plastic deformation and smectitic clay (corrensite?). Traces of visible intergranular what? Is something missing?. Abundant framework grains are chert (20 percent), basic volcanics (14 percent), and ductile grains (12 percent). 


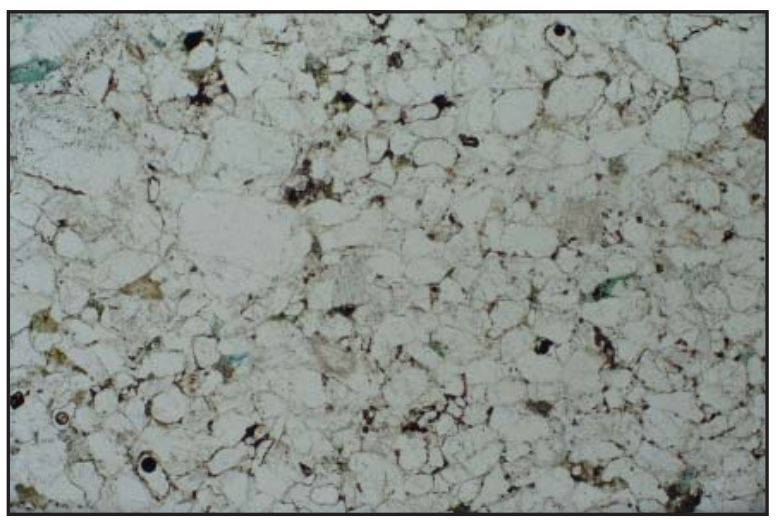

Step Mountain, Corehole 27, 1985-22, Late Triassic to Jurassic, PL, 40X. Fine-grained, well sorted, highly quartzose sandstone cemented by quartz overgrowths and suturing. Point-count measured porosity in this sample is 2 percent. Quartz forms 95 percent of the framework fraction.

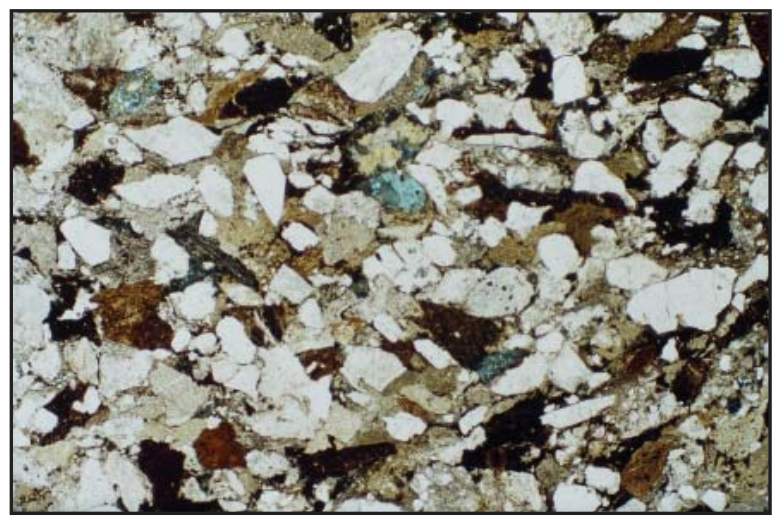

Preacher Creek, Corehole 5, 1986-67, Paleogene, PL, 40X. Medium-grained, well sorted, argillaceous chertand ductile-rich lithic sandstone cemented by suturing, plastic deformation, and siderite. Point-count measured porosity is 0 percent. The major framework components are quartz (27 percent), chert (33 percent), and ductile grains (25 percent; shale, mudstone, argillite, and phyllite).

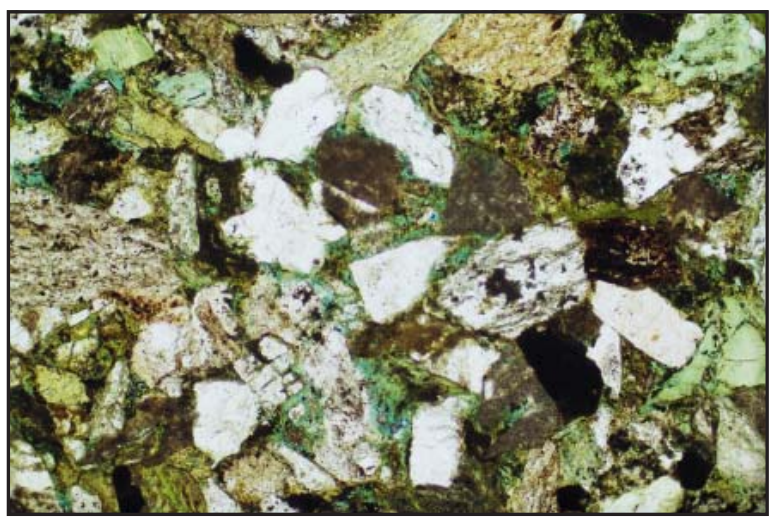

Maypole Hill, Corehole 31, 1985-18, Early Eocene, PL, 100X. Plastic deformation of ductile grains (including altered basic volcanic rock fragments) is the major mechanism of porosity loss in this highly lithic sandstone. Minor agents of porosity loss are matrix infill (4 percent), authigenic clay (3 percent; corrensite?), and suturing.

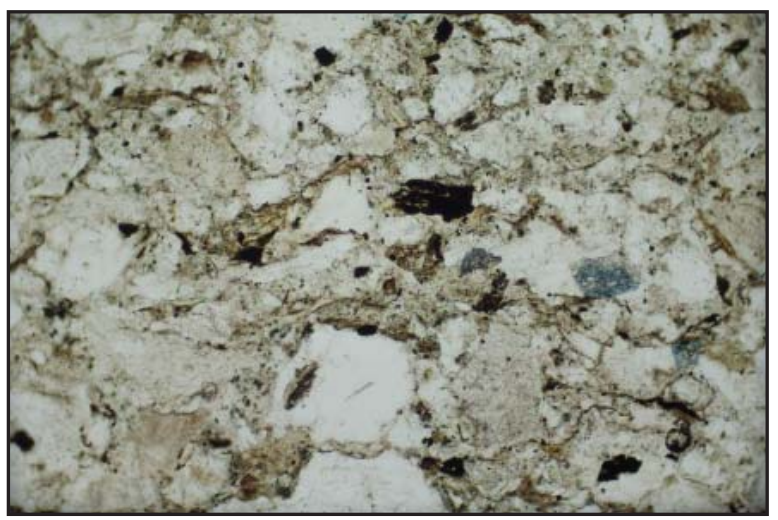

Hodzana River \#2, Corehole 8, 1987-95, Age unknown, PL, 100X. Suturing and plastic deformation are the major mechanisms of porosity destruction. Minor agents of porosity loss are quartz overgrowths ( 4 percent) and matrix infill (6 percent). 


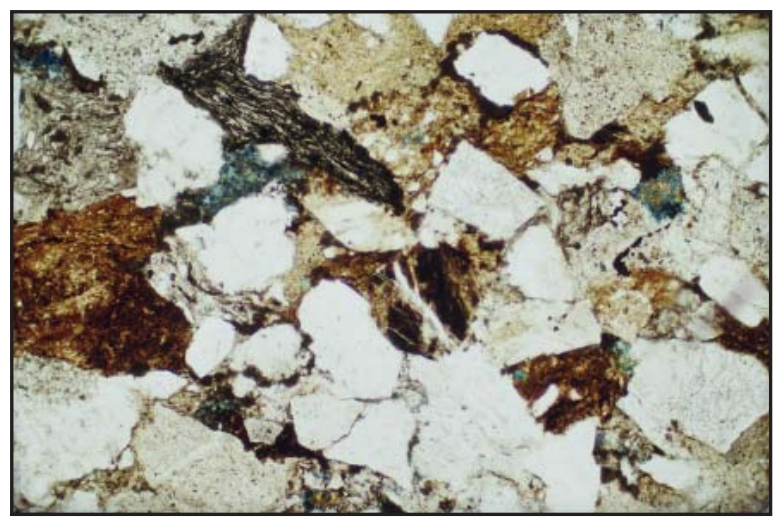

Preacher Creek, Corehole 5, 1986-67, Paleogene, PL, 100X. The lack of visible porosity is attributable to a combination of siderite and ankerite cements, plastic deformation of ductile grains, and suturing of chert. A highly deformed phyllite is at the upper left.

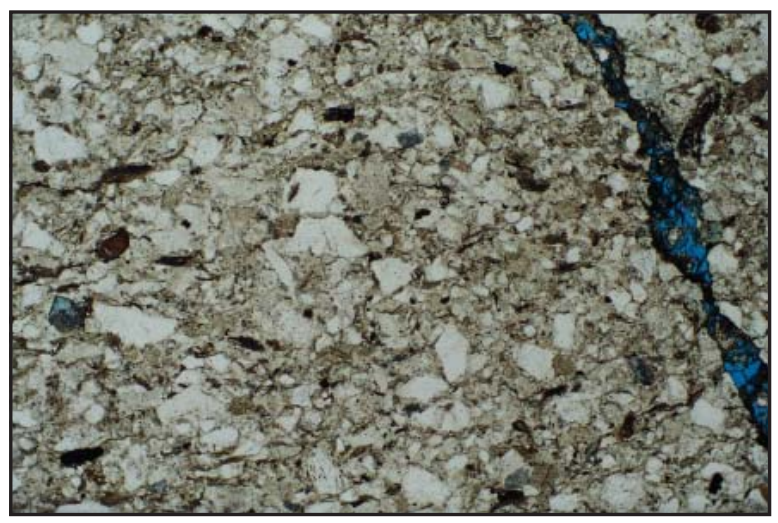

Hodzana River \#2, Corehole 8, 1987-95, Age unknown, PL, 40X. Fine-grained, well-sorted, slightly argillaceous chert- and ductile-rich lithic sandstone cemented by suturing and plastic deformation. Point-count measured porosity is 0 percent. Quartz (48.9 percent), chert (21.3 percent), and phyllite (15.3 percent) are the major framework components. Matrix content is 6 percent.

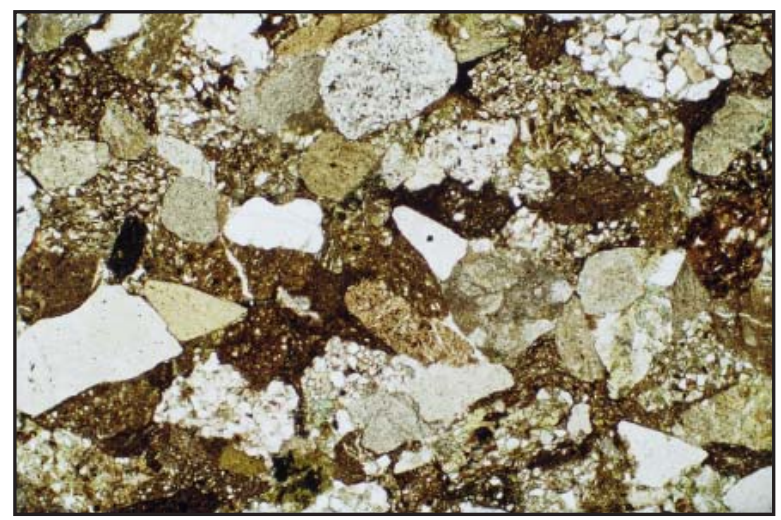

Eagle Trough, Corehole 26, 1985-68.5, Middle to late Albian, PL, 100X. Visible porosity destroyed by plastic deformation and chert suturing. Mudstone framework grains are extensively deformed and are dark brown and mottled in this image.

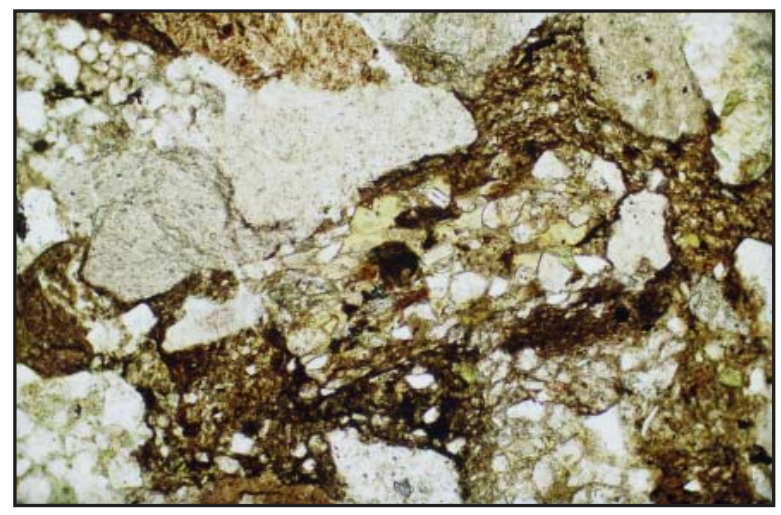

Eagle Trough, Corehole 26, 1985-68.5, Middle to late Albian, PL, 200X. Visible porosity destroyed by plastic deformation and chert suturing. Grain at center is a feldspathic-lithic sandstone cemented by chlorite or smectitic clay. Mudstone extensively deformed. 


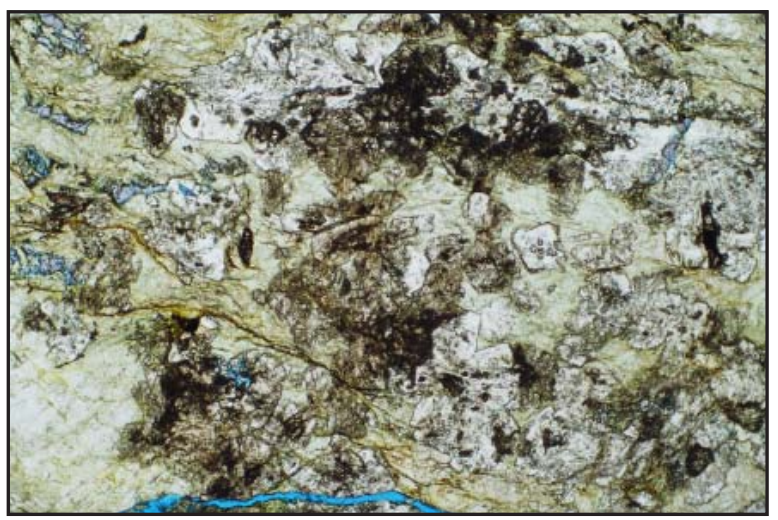

Coal Creek, Corehole 3, 1986-15, Oligocene, PL, 40X. Porphyroblasts of quartz and epidote containing abundant fine inclusions float in a mass of pale green chlorite and colorless muscovite or pyrophyllite. Sphene, zoisite, and plagioclase are present in minor amounts.

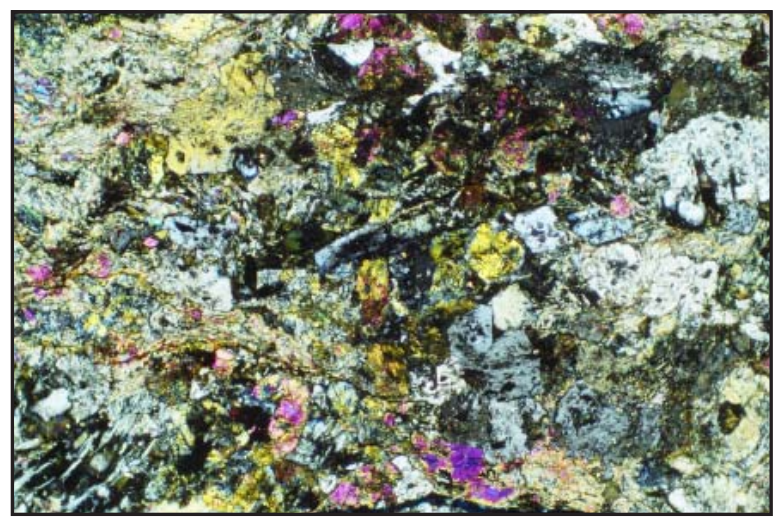

Coal Creek, Corehole 3, 1986-15, Oligocene, XP, 40X. View similar to previous view but in crossed polarizers. The grains with the highest birefringence are epidote. 